MA-S

C. 2

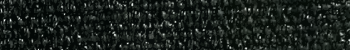

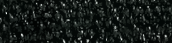

$+2$

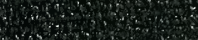


$M_{2-S}$

C. 2

HARVARD UNIVERSITY

ชู

Library of the

Museum of

Comparative Zoology 


31,396

LELAND STANFORD JUNIOR UNIVERSITY PUBLICATIONS UNIVERSITY SERIES

The Effect of a Strictly Vegetabie Diet on the Spontaneous Activity, the Rate of Growth, and the Longevity of the Albino Rat

BY

JAMES ROLLIN SLONAKER ASSISTANT PROFESSOR OF PHYSIOLOGY

WITH ONE PLATE AND FIFTEEN TEXT FIGURES

STANFORD UNIVERSITY, CALIFORNIA

PUBLISHED BY THE UNIVERSITY 1912 


\section{UNIVERSITY SERIES}

Inheritance in Silkworms, I. Nernon L. Kellogg, Professor of Entomology. 89 pp., 4 plates. 1908. Price, \$1.00.

The Opisthobranchiate Mollusca of the Branner-Agassiz Expedition to Brazil. Frank Mace MacFarland, Professor of Histology. I05 Pp., I9 plates. 1909. Price, \$1.00.

A Study of the Normal Constituents of the Potable Water of the San Francisco Peninsula. John Pearce Mitchell, Assistant Professor of Chemistry. 70 pp., I map. I9ro. Price 5oc.

Synopsis of the True Crabs (Brachyura) of Monterey Bay, CaliFORNIA. Frank Walter Weymouth. 64 pp., I4 plates. I9Io. Price 50c.

The Osteology of Certain Scombroid Fishes. Edwin Chapin Starks, Assistant Professor of Zoology. 49 pp., 2 plates, I text figure. I9I I. Price, 5oc.

A Physical Theory of Electrification. Fernando Sanford, Professor of Physics. 69 pp., 2 plates, II text figures. I9II. Price, $50 c$.

The Matzke Memorial Volume. Papers by John Ernst Matzke, late Professor of Romanic Languages, and Thirteen Colleagues. 162 pp. I911. Price, $\$ 1.00$.

Das Historische Präsens in der Älteren Deutschen Sprache. Bruno Boezinger, Assistant Professor of Germanic Languages. 9I pp. 1912. Price, 50c. 
LELAND STANFORD JUNIOR UNIVERSITY PUBLICATIONS UNIVERSITY SERIES

The Effect of a Strictly Vegetable Diet on the Spontaneous Activity, the Rate of Growth, and the Longevity of the Albino Rat

BY

JAMES ROLLIN SLONAKER ASSISTANT PROFESSOR OF PHYSIOLOGY

WITH ONE PLATE AND FIFTEEN TEXT FIGURES

STANFORD UNIVERSITY, CALIFORNIA

PUBLISHED BY THE UNIVERSITY

APRIL 2, I9I 2 


$$
\begin{gathered}
M a-S \\
C .2
\end{gathered}
$$

StANFord University
Press 


\section{THE EFFECT OF A STRICTLY VEGETABLE DIET ON THE SPONTANEOUS ACTIVITY, THE RATE OF GROWTH, AND THE LONGEVITY OF THE ALBINO RAT.*}

\section{INTRODUCTION.}

The study of dietetics today occupies one of the most important places in the field of physiological investigation. Many popular articles have appeared in the past few years advocating this or that diet as best adapted to the needs of man. The argument is usually based on the personal opinion of the writer or the effects a certain diet may have had upon him. The personal idiosyncrasies which appear in these articles are too numerous to mention. Such writings are of no scientific value, and only show the trend of a certain class of people.

In contrast to these popular articles appear the writing of various scientific men giving the results of their investigations. These results are based on the comparative digestibility and absorption of the different foods and upon their ability to maintain nitrogenous equilibrium in the animal experimented upon.

The tendency of humanity is to go to the extremes, and nowhere is this more manifested than in dietetics. One class, vegetarians, maintains that man should abstain exclusively from animal foods, the other class claims that the human alimentary tract is more adapted to omnivorous food than to a strictly vegetable diet.

Vegetarianism as used by most people is a misnomer. The larger proportion of the so-called vegetarians partake freely of such animal foods as milk, eggs, butter, cheese and the like. A few, the fruitarians, live wholly on nuts and fresh fruits. Another small group live on nuts, fruits, legumes and vegttables, either in the raw or cooked state. The much larger number of vegetarians (?) live on a mixed diet which differs from the ordinary mixed diet in only one respect-the absence of meat.

Most investigators have studied the effects of a certain diet on the animal for a limited time, which in most cases is insufficient to warrant

*From the Physiological Laboratories of Stanford University. 
such sweeping conclusions. Because an animal is able to maintain its weight and health for a limited time, is no argument that it could do so for its entire life. Neither has the effect on the offspring been ascertained. Such results can only be obtained by continuing the experiment during the lifetime of the animal and succeeding generations.

The present experiment was undertaken to determine as fully as possible the comparative effect of a strictly vegetable diet, and an omnivorous diet, upon the spontaneous energy of the animal as manifested by its voluntary activity, the effect on its growth, and on the length of its life. An experiment is now under way to study the effect on the progeny. No attempt has been made to study the income and outgo of nitrogen.

\section{MATERIALS AND APPARATUS.}

In order that such an experiment may be of value a number of similar animals must be used, and the environment of these must be the same in every respect, with the exception of diet. ${ }^{1}$

In this experiment sixteen rats were used. To secure these as nearly alike as possible, sisters were mated to the same male. After numerous trials, lasting more than a year, two sister rats of approximately the same size, which had been mated to the same male, gave birth to eight each, just a day apart. Previous observations ${ }^{2}$ have shown that the young of a litter of three not only averaged heavier at birth than those of a litter of ten, but also gained more rapidly during the nursing period and had a better start at the weaning time than those of the larger litter. Also the age of the mother had an effect on the size of the litter and the average weight of the young. Very young mothers were less prolific than older females.

$\mathrm{Minot}^{3}$ found in his observations on the guinea pig that the average young of a litter of one weighed 85.5 grams, and the average of a litter of eight 52.2 grams. Also that the males averaged heavier (7I grams) than the females (70.2 grams). A similar condition exists between the sexes of the albino rat. This difference in weight of the two sexes becomes much more marked as the animals grow older. One should therefore have rats of the same age, of as nearly as possible the same parentage, the same number in the litter, and the same number of each sex. Owing to the fact that it is difficult to determine the sex of the young rats with accuracy, the sexes were not distributed as I would have wished.

These sixteen young were arranged and designated as follows: 
No. I and No. 2 from litter A, and No. 3 and No. 4 from litter B, were put into revolving cages to be used as omnivorous feeders in determining their activity; No. 5 and No. 6 from litter A, and No. 7 and No. 8 from litter B, were put in revolving cages to be used in ascertaining the amount of work the vegetarian feeders would perform; No. 9 and No. Io from litter A, and No. II and No. I2 from litter B, were put in stationary cages for omnivorous controls; and No. I3 and No. I4 from litter A, and No. I5 and No. I6 from litter B, were placed in stationary cages for vegetarian controls. Thus each litter was equally and uniformly distributed. Unfortunately the sexes were not ideally grouped. The following table illustrates the manner in which the young were distributed.

\begin{tabular}{|c|c|c|c|c|c|c|c|c|c|c|c|}
\hline \multicolumn{3}{|c|}{$\begin{array}{l}\text { Omnivorous Exer- } \\
\text { cised Rats }\end{array}$} & \multicolumn{3}{|c|}{$\begin{array}{l}\text { Vegetarian Exer- } \\
\text { cised Rats }\end{array}$} & \multicolumn{3}{|c|}{$\begin{array}{c}\text { Omnivorous Control } \\
\text { Rats }\end{array}$} & \multicolumn{3}{|c|}{$\begin{array}{l}\text { Vegetarian Control } \\
\text { Rats }\end{array}$} \\
\hline Litter & No. & Sex & Litter & No. & Sex & Litter & No. & Sex & Litter & No. & Sex \\
\hline A & I & Male & A & 5 & Mal & A & 9 & Male & A & I3 & ale \\
\hline “ & 2 & & & 6 & Female & & IO & & & I4 & Iale \\
\hline B & 3 & Fema & B & 7 & " & B & I I & $\mathrm{Fe}$ & B & I5 & “ \\
\hline a & 4 & & " & 8 & "6 & $"$ & I2 & $\mathrm{Ma}$ & "6 & I6 & “ \\
\hline
\end{tabular}

Each rat was thus confined in a cage by itself, which served as its home for its entire lifetime, and from which it was taken at intervals of about two weeks for a time sufficient to weigh the rat and clean its cage.

The apparatus for recording the activity has already been described, ${ }^{4}$ but may be briefly given again. It consisted of a series of eight cylindrical cages which revolved on stationary axles to which were attached the nest boxes. The food and water boxes were attached to the ends of the nest boxes. The cage thus revolved about the stationary nest box whenever the rat ran. Automatic devices were attached to register the number of revolutions and to record them on paper kept moving by a continuous roll kymograph. The first device being read in the morning and in the evening gave the daily and nightly run of each rat through its lifetime. The second arrangement showed the distribution of the activity of each rat for each twenty-four hours during its whole life. These records were of great assistance in showing the peculiarities of activity which occurred at different ages.

This apparatus was therefore only adapted to recording the running activity of the animals. Previous observations ${ }^{2}$ have shown that the running activity of the rat is proportional to the other activities. 
Changes in the amount of the running activity are correct indicators of similar fluctuations in the other activities of the animal.

\section{FEEDING.}

No attempt was made to give a definite amount of protein food in the diet nor to try to maintain nitrogenous equilibrium. The diet was varied as much as possible, and the amount of food given was more than was eaten before the feeding time on the following day. The feed and water boxes were then cleaned and a new supply given. Cracked corn was always given. The young were weaned at the age of 28 days and placed in their respective cages, as already described. A rich mixed diet, consisting largely of bread and milk with an occasional feed of baked beans and meat hash, was given all to prevent any disastrous effects resulting from the sudden change in environment and methods of feeding. This mixed diet was continued for twenty-eight days. At this age (fifty-six days) all appeared perfectly healthy and normal in every respect. They had each made a normal gain. The males averaged 70.1 grams and the females 59.3 grams.

The difference in the character of the food was introduced at this time, the one group being designated vegetarians, and the other, omnivorous feeders. These two groups were fed exactly the same food each day, with the exception of meat and other animal foods which were given about three times a week to the omnivorous feeders in addition to the vegetable food. The vegetable foods were as rich in protein as it was possible to obtain from this class of foods, and consisted of such articles as the following: fresh vegetables, such as lettuce, kale, cabbage, cauliflower, clover and celery; cooked vegetables, such as white, corn, brown and graham bread, biscuits, buckwheat cakes, doughnuts, crackers, cookies, oatmeal mush, fried cornmeal mush, dumplings, corn, rice, baked beans, potatoes, carrots and onions; nuts, fruits and grains, such as almonds, English walnuts, apples, cracked corn, wheat, and corn meal. Occasionally, when the vegetarians seemed to be losing ground too fast, a feed of cheese, milk, or some other animal food was given. This was done only a few times soon after the vegetarians were first put on their exclusive diet.

As can be readily seen, the above articles composing the vegetarian diet are either found on our tables or can readily be procurred from shops. Some of them contained small portions of animal food, i.e., graham muffins usually contain an egg and milk, bread often contains milk, doughnuts and several other articles contain animal fat. As only 
very small amounts of animal food were present as compared to a large quantity of vegetable food, I have called this a strictly vegetable diet, at the same time realizing it is not absolutely such a diet.

The amount of food given to each rat was not weighed, but measured as accurately as possible with a spoon, or by pieces of equal size.

The following few days' diet taken at random will serve to show the variety of food and its frequency.

April 23. Cooked corn, lettuce, cracked corn and water.

April 24. Water-soaked bread, almonds, lettuce, cracked corn and water. April 25. Baked beans, lettuce, cracked corn and water.

Omnivorous had also meat.

April 26. Graham muffins, almonds, cracked corn and water.

April 27. Water-soaked bread, lettuce, cracked corn and water.

April 28. Water-soaked bread, almonds, cracked corn and water.

April 29. Cracked corn and water.

April 30. Mashed potatoes, lettuce, cracked corn and water.

Omnivorous had also meat.

April 3I. Water-soaked bread, buckwheat cakes, cracked corn and water.

Another example at another season of the year is as follows:

Nov. I4. Bread, cracked corn and water.

Nov. I5. Potatoes, macaroni, cracked corn and water.

Omnivorous had also meat.

Nov. I6. Bread, oatmeal mush, cracked corn and water.

Omnivorous had also meat and bread hash.

Nov. I7. Water-soaked bread, cracked corn and water.

Nov. I8. Water-soaked bread, cracked corn and water.

Omnivorous had also meat and bread hash.

The amount of meat given to each of the omnivorous rats was usually small, consisting of but a few grams. It was given on an average two or three times each week.

We have thus sixteen rats as nearly alike in regard to age, parentage, size and tendencies as it is possible to obtain, subjected to the same environments, fed the same food with the exception that the eight omnivorous feeders had a few grams of animal food added to their diet about three times each week. It is obvious, therefore, that whatever differences may be found between these two groups of rats in regard to their activity, rate of growth, and longevity must be due wholly to the presence and absence of animal food in the two diets. 


\section{ACTIVITY.}

In studying the characteristics of the activity one needs to refer to the kymograph records. Figures I to Io inclusive are reproductions of such records, and show the activity of each rat for twenty-four consecutive hours at different ages. By comparing these figures a great difference is noticed in the activity at different ages.

Figure I represents the activity of each rat at the age of thirtytwo days, and just four days after they had been weaned and placed in the revolving cages. There is no regularity in the distribution of the activity and periods of rest. Neither is there any apparent tendency to be more active at one time in the twenty-four hours than at another. They were restless, playful and filled with a spirit of investigation. Since they were all fed at this time on the same diet, any differences in the character of the activity may be attributed to individual variation.

In Figure 2, which shows the distribution of the activity at the age of six months, two important things are noticed. First, the great bulk of the activity occurs during the evening and early night time; second, the omnivorous rats $(\mathrm{O})$ are more active than the vegetarians (V). There is more or less random running for an hour or so before and after the feeding time (4 p.m.), but the most is done during the night.

At the age of eleven months (Figure 3 ) the periods of activity and rest are more sharply defined. Also the difference in the amount of voluntary activity of the two classes is very obvious. The activity of the vegetarians is approaching closely in appearance that of old age. ${ }^{2}$

In Figure 4 the activity at the age of sixteen months is seen. Some days previous to this record the feeding time was changed to the morning to see what effect it would have on the distribution of the activity. The main bulk is seen to remain constant, but the usual random running which occurs at the feeding time has shifted to the morning. At this age two of the vegetarians have died and the other two compare very unfavorably with the work of the omnivorous.

Figure 5, which represents the activity at the age of twenty-one months, shows that when the feeding time is returned to the afternoon the periods of activity and rest are sharply defined. The omnivorous feeders are still quite active when compared to the remaining vegetarians.

At the age of twenty-five months all the vegetarians were dead (Figure 6). The records of the omnivorous rats show a marked tendency toward old age. Especially is this true in No. I and No. 4. 
. : 


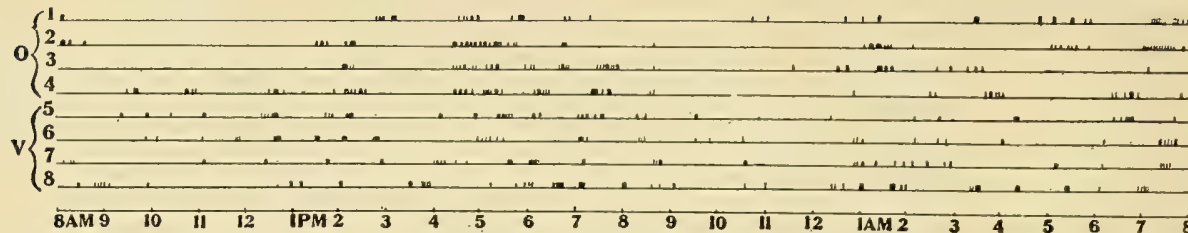

Fig. I. Graphic records showing the distribution of the activity of each of the exercised rats as recorded on the kymograph paper. The rats were 32 days old and had been weaned and put in their cages but four days before.

$\mathrm{O}$ and $\mathrm{V}$ refer to omnivorous and vegetarian rats respectively.

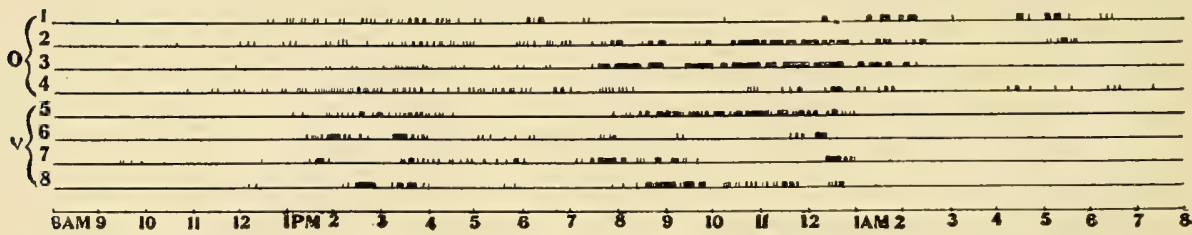

Fig. 2. Graphic records of activity of omnivorous (O) and vegetarian rats (V) at the age of 6 months.

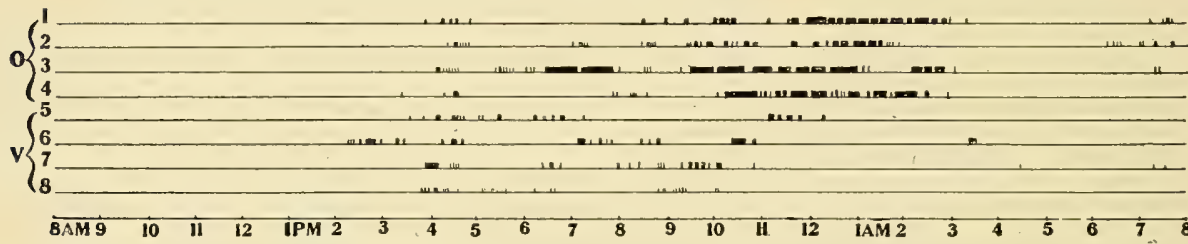

Fig. 3. Graphic records of activity of omnivorous (O) and vegetarian rats (V) at the age of II months.

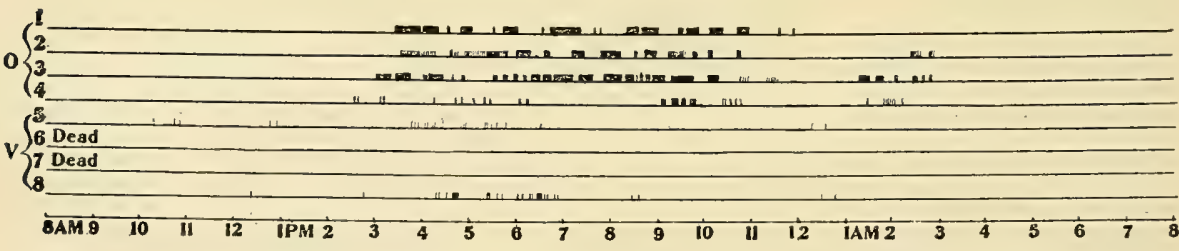

Fig. 4. Graphic records of activity of omnivorous (O) and vegetarian rats (V) at the age of 16 months.

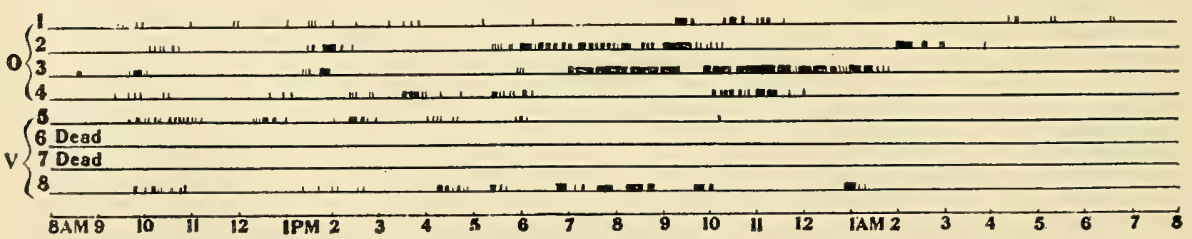

Fig. 5. Graphic records of activity of omnivorous (O) and vegetarian rats (V) at the age of 21 months. 


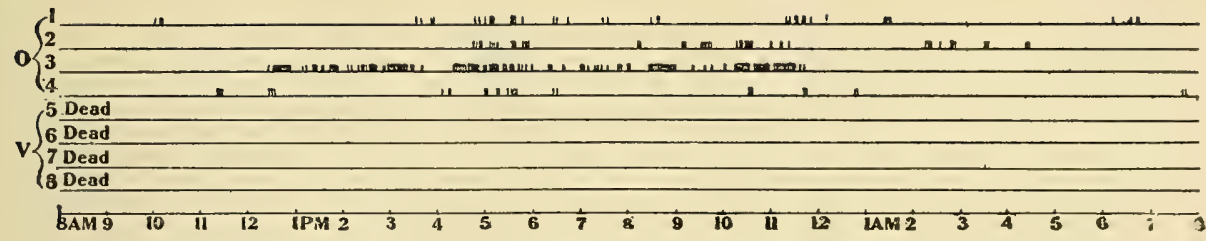

Fig. 6. Graphic records of activity of omnivorous (O) and vegetarian rats (V) at the age of 25 months.

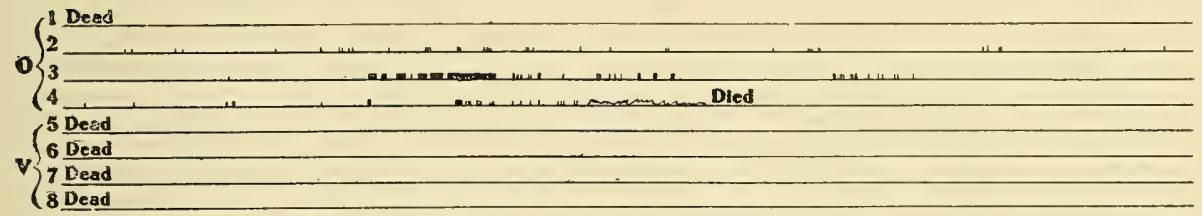

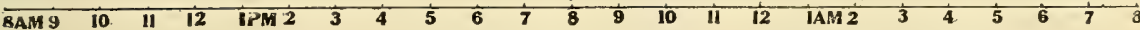

Fig. 7. Graphic records of activity of omnivorous (O) and vegetarian rats (V) at the age of 26 months.

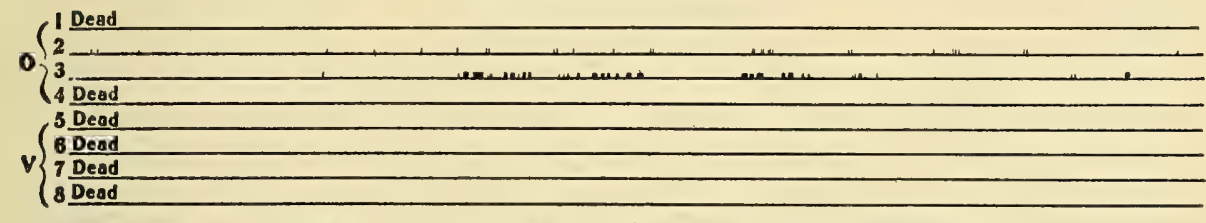

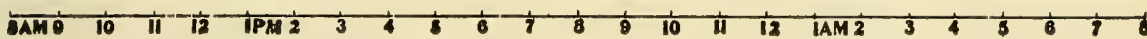

Fig. 8. Graphic records of activity of omnivorous $(\mathrm{O})$ and vegetarian rats $(\mathrm{V})$ at the age of 28 months.

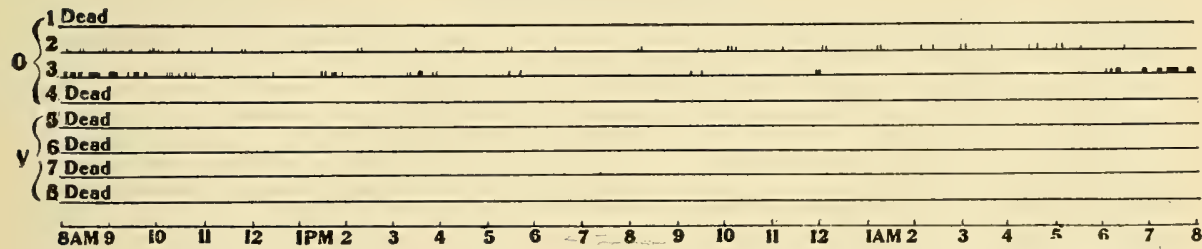

Fig. 9. Graphic records of activity of omnivorous (O) and vegetarian rats (V) at the age of $3 \mathrm{I}$ months.

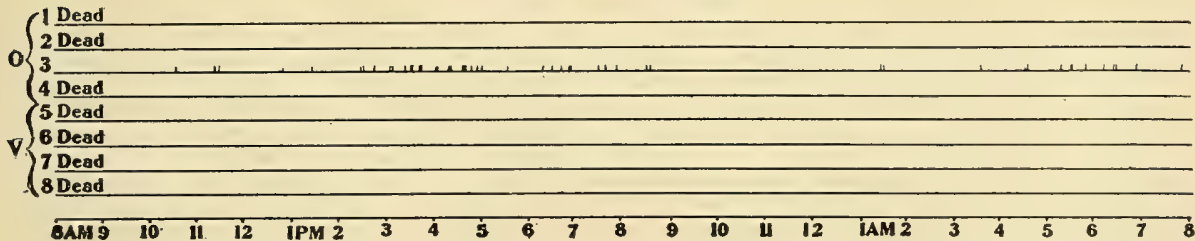

Fig. Io. Graphic records of activity of omnivorous (O) and vegetarian rats (V) at the age of 34 months. 

The remaining figures ( $7,8,9$ and 10) represent the records for the ages twenty-six, twenty-eight, thirty-one and thirty-four months_respectively. No. 4 in Figure 7 shows the death struggle of this rat, which ended a little before io p.m.

In comparing these different records of activity, one notices that in the young rats the periods of activity and rest are of short duration and have no definite arrangement so far as the time of the day is concerned. As the rats grow older the activity becomes greater and occurs more and more during the night time, the periods of rest being confined to the daytime. This continues until the rats reach the prime of life. After some months of almost uniform activity there is a gradual reduction, and the distribution and amount of work done approaches that of youth. It also shows that the vegetarians are not as active, that they age more early, and that their duration of life is shorter than the omnivorous rats.

Since all the animals were fed on a mixed diet for twenty-eight days after commencing the experiment, any difference in activity during this period must be considered due to individual variation. This variation is sometimes very noticeable, as seen in Table $I$. This table represents the average number of revolutions of five consecutive days of each rat at the ages indicated. There is not a gradual and regular increase in the amount of running done by each, but fluctuations-now greater, now less. At first this was thought to be due to making the average from too small a number of days. Therefore another table (Table II) was made, by taking the average run of each sex of each group for a whole month. The figures in the column of the omnivorous males thus represent the average of thirty days' run of three individuals. But here again we see the lack of a uniform increase. In other words, the activity manifests itself rhythmically. No doubt if the number of individuals had been greater the results would have been more uniform. In a former paper I have discussed the causes of these fluctuations. ${ }^{2}$

Table II is put in the form of curves in Figure II. The rhythmical variations are very conspicuous. These fluctuations also correspond in many cases both in regard to time and appearance. For example, from the beginning to the third month there is a rapid rise in the curves. showing a great increase in the daily activity. This was, no doubt, due to the feed, for they were all fed on a strong mixed diet for almost a month, and on rich food for almost two months. The effect of this food carried them over apparently till the end of the third month, when they began to feel the effects of the lack of it. This was followed in a general reduction of amount of daily activity in all except the omnivorous 


\begin{tabular}{|c|c|c|c|c|c|c|c|c|}
\hline & \multicolumn{4}{|c|}{ OMNIVOROUS RATS } & \multicolumn{4}{|c|}{ VEGETARIAN RATS } \\
\hline$\underset{\text { in }}{\mathrm{Age}}$ & No. I & No. 2 & No. 3 & No. 4 & No. 5 & No. 6 & No. 7 & No. 8 \\
\hline Mos. & Male & Male & Female & Male & Male & Female & Female & Female \\
\hline $\mathbf{I}$ & 348 & 1002 & 620 & 448 & I I 82 & 752 & 318 & 970 \\
\hline 2 & 1200 & II 24 & $2 \operatorname{II} 8$ & I336 & 1964 & 668 & 716 & 1952 \\
\hline 3 & 790 & 886 & I956 & 1832 & г6เ 8 & 682 & I396 & $223^{8}$ \\
\hline 4 & 5028 & 5850 & 5782 & 9406 & 2150 & 54.2 & 2870 & 1468 \\
\hline 5 & 1206 & 3930 & 7280 & 834 & 420 & 657 & I206 & 3496 \\
\hline 6 & 540 & 1644 & 8482 & 540 & 596 & 920 & I I 70 & 1472 \\
\hline 7 & I 307 & 3144 & IOI85 & 3574 & IO84 & I 128 & 3244 & I904 \\
\hline 8 & 2024 & 3274 & 9518 & 4276 & 676 & 5652 & 2400 & 3884 \\
\hline 9 & 6002 & 7574 & 8930 & 2836 & 836 & 656 & 8962 & 4106 \\
\hline 10 & 2618 & 4398 & 8260 & 2882 & 858 & 578 & 876 & 2962 \\
\hline I I & 3620 & 2096 & 8640 & 2310 & 1006 & 340 & 670 & 882 \\
\hline 12 & 2186 & 4258 & 8902 & 2616 & I I 44 & 528 & 898 & 1004 \\
\hline 13 & 4964 & 7066 & I IO44 & 3084 & 602 & 46 & 316 & 708 \\
\hline 14 & 3860 & 6374 & I0992 & 3004 & I68 & $\ldots$ & 524 & 634 \\
\hline 15 & I 428 & 4768 & 8198 & $255^{6}$ & 90 & .... & 918 & 96 \\
\hline 16 & 1006 & 2642 & I 3002 & I364 & 342 & . & 68 & 96 \\
\hline I7 & 2684 & 4776 & 5982 & I998 & 84 & $\ldots$ & .... & 72 \\
\hline I8 & 744 & 2364 & 9732 & 1512 & 88 & & ... & 22 \\
\hline I9 & 996 & 2476 & 8312 & 808 & 70 & - & $\ldots$ & 60 \\
\hline 20 & 806 & $205^{6}$ & 9658 & 720 & 82 & $\ldots$ & $\ldots$ & 24 \\
\hline $2 I$ & 690 & I 520 & 22 IO & 482 & 56 & $\ldots$ & $\ldots$ & $5^{8}$ \\
\hline 22 & 336 & I8Io & 5468 & 290 & 52 & $\ldots$ & $\ldots$ & 22 \\
\hline 23 & I696 & I680 & 3188 & 456 & 40 & $\ldots$ & $\ldots$ & 88 \\
\hline 24 & 380 & I 352 & 3I00 & 220 & $\ldots$ & ... & $\ldots$ & $\ldots$ \\
\hline 25 & $94^{*}$ & 1466 & 4612 & I96 & $\cdots$ & $\ldots$ & $\ldots$ & $\ldots$ \\
\hline 26 & ... & I 88 & 2538 & $48^{*}$ & $\ldots$ & $\cdots$ & $\cdots$ & $\ldots$ \\
\hline 27 & ... & 160 & 1968 & $\ldots$ & $\ldots$ & $\cdots$ & $\ldots$ & $\ldots$ \\
\hline 28 & $\ldots$ & I80 & $5 I 7 I$ & ... & $\ldots$ & $\ldots$ & $\cdots$ & $\ldots$ \\
\hline 29 & ... & 72 & 2424 & $\ldots$ & $\ldots$ & $\ldots$ & $\ldots$ & $\ldots$ \\
\hline 30 & $\ldots$ & 56 & 2832 & $\ldots$ & $\ldots$ & $\ldots$ & $\ldots$ & $\ldots$ \\
\hline $3 I$ & $\ldots$ & $28 *$ & I706 & $\ldots$ & $\ldots$ & $\ldots$ & $\cdots$ & $\ldots$ \\
\hline $3^{2}$ & ... & $\ldots$ & 2312 & $\ldots$ & $\ldots$ & $\cdots$ & $\ldots$ & $\ldots$ \\
\hline 33 & $\ldots$ & $\ldots$ & 488 & $\ldots$ & $\ldots$ & $\cdots$ & $\cdots$ & $\ldots$ \\
\hline 34 & $\cdots$ & $\cdots$ & $\begin{array}{c}435 \\
60 *\end{array}$ & $\ldots$ & $\cdots$ & $\cdots$ & $\cdots$ & $\cdots$ \\
\hline & & $\cdots$ & $\infty 0^{\circ}$ & $\ldots$ & ... & & ... & $\cdots$ \\
\hline
\end{tabular}

TABLE I.-Average daily revolutions of the omnivorous and vegetarian rats at ages indicated.

female, which remained practically unchanged. Then, with the excepttion of the vegetarian female, there was another general increase up to the fifth month. Again, at the tenth month, all show an increase, excepting the vegetarian male, which shows a slight decrease.

*The number of revolutions during the 24 hours previous to death. 


\begin{tabular}{|c|c|c|c|c|}
\hline \multirow[b]{2}{*}{$\begin{array}{c}\begin{array}{c}\text { Age } \\
\text { in } \\
\text { Months } \\
\end{array} \\
\end{array}$} & \multicolumn{2}{|c|}{ OMNIVOROUS } & \multicolumn{2}{|c|}{ VEGETARIAN } \\
\hline & $\begin{array}{c}\text { Male } \\
\text { (Avg. 3) }\end{array}$ & $\begin{array}{l}\text { Female } \\
\text { (Avg. I) }\end{array}$ & $\begin{array}{c}\text { Male } \\
\text { (Avg. I) }\end{array}$ & $\begin{array}{c}\text { Female } \\
\text { (Avg. 3) }\end{array}$ \\
\hline$I$ & 73 & 102 & 68 & 53 \\
\hline 2 & 689 & 724 & 1169 & IO4O \\
\hline 3 & 2455 & 2,944 & 3542 & 2017 \\
\hline 4 & 642 & 3,014 & I 853 & 1273 \\
\hline 5 & 4375 & 6,835 & 5021 & 75 \\
\hline 6 & 3286 & 8,843 & 845 & 146 \\
\hline 7 & 3405 & I3,308 & 1242 & II75 \\
\hline 8 & 3673 & 10,898 & I $2 \mathrm{II}$ & 2188 \\
\hline 9 & 3535 & 9,688 & 1057 & 2156 \\
\hline Io & 4717 & I I, 643 & 828 & 2316 \\
\hline I I & 3119 & 10,136 & 998 & 905 \\
\hline I2 & 2935 & IO, 5 I 3 & IOIO & 738 \\
\hline I3 & 3957 & 9,684 & 826 & 680 \\
\hline I4 & 5081 & I I 6 I 3 & $45^{8}$ & 482 \\
\hline I5 & 2285 & 9, I IO & 5 I7 & 519 \\
\hline 16 & 2247 & 8,692 & I 40 & 267 \\
\hline I7 & 2069 & 9,027 & 179 & 29 \\
\hline I8 & 2262 & 7,579 & 99 & 26 \\
\hline 19 & 2212 & 9,357 & 96 & 7 \\
\hline 20 & I 599 & 9,247 & 54 & $2 I$ \\
\hline $2 \mathrm{I}$ & 980 & 6,940 & 55 & I6 \\
\hline 22 & 1273 & 7,156 & 37 & I3 \\
\hline 23 & 1062 & 5,730 & 81 & I6 \\
\hline 24 & 727 & 3,664 & ... & $\ldots$ \\
\hline 25 & 746 & 3,529 & ... & $\ldots$ \\
\hline 26 & 266 & 3,909 & $\ldots$ & $\ldots$ \\
\hline 27 & 105 & 3,774 & ... & ... \\
\hline 28 & I 49 & 3,609 & ... & $\ldots$ \\
\hline 29 & I5 & 3,339 & ... & ... \\
\hline 30 & 25 & 2,808 & ... & ... \\
\hline $3 I$ & IO & I,9 I I & $\ldots$ & ... \\
\hline 32 & 4 & $3, \mathrm{I}-34$ & $\ldots$ & ... \\
\hline 33 & $\ldots$ & 2,033 & $\ldots$ & $\ldots$ \\
\hline 34 & $\ldots$ & 320 & ... & $\ldots$ \\
\hline
\end{tabular}

TABLE II.-Average daily work as indicated by the number of revolutions computed by dividing the total run of the month previous by 30 .

It is especially noticeable that the curves representing the two sexes of the omnivorous feeders correspond much more closely in their fluctuations than those of the vegetarian feeders. In fact after the third month similarity in the character and time of these fluctuations of the 
omnivorous and vegetarian feeders grows rapidly less and less. The same may be said regarding the amount of daily activity of the two classes. The omnivorous female far surpasses all others. The omnivorous male comes next in order. Then follows the vegetarian female,

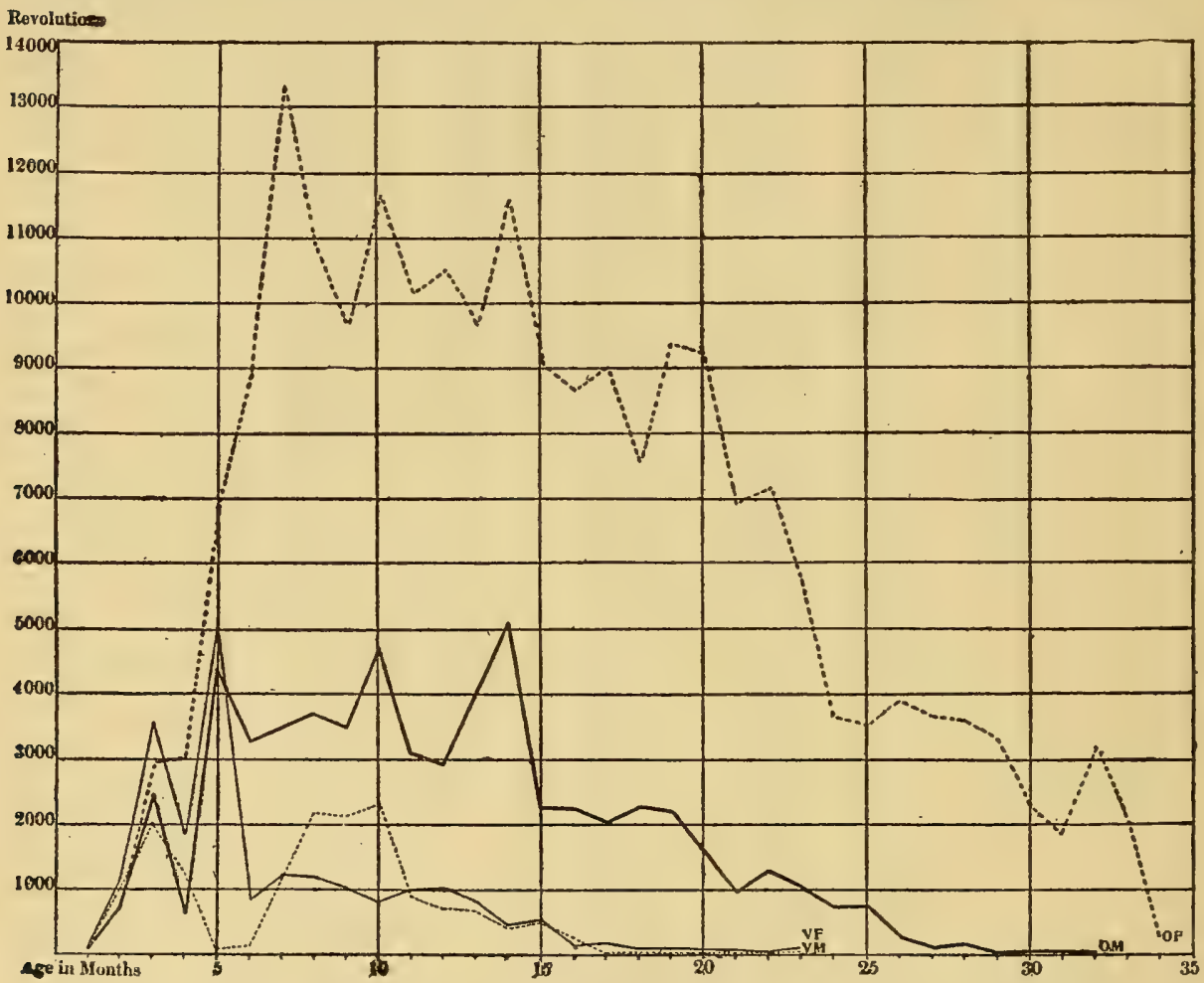

Fig. II. Curves representing the average daily activity of each sex of the exercised rats at the ages indicated. The heavy solid line $(O M)$ is the omnivorous males, the heavy dotted line $(O F)$ is of the omnivorous females. The light solid line $(V M)$ is the vegetarian males. The light dotted line $(V F)$ is the vegetarian females.

closely followed by the vegetarian male. The females of each class thus surpass the males of the same group in average daily activity.

When we consider the time in life at which these rats do the greatest amount of daily running we see, on consulting the curves of Figure I I, that it occurs in both classes at an early age in life, usually between the seventh and twelfth month. In the omnivorous feeders it is a little later than in the vegetarians. In a former experiment ${ }^{2}$ it was ascertained that the greatest average daily run of the normal male and female occurred when they had reached a trifle more than one-third of their 
natural lifetime. In this experiment the vegetarians seem to have done their best day's work when about one-fourth of their life had passed. This was equivalent to about one-sixth of the lifetime of the normal omnivorous rat.

Let us now consider the total amount of work, as indicated by the

\begin{tabular}{|c|c|c|c|c|c|c|c|c|}
\hline \multirow{3}{*}{ 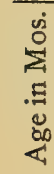 } & \multicolumn{3}{|c|}{ OMNIVOROUS EXERCISED } & \multirow{2}{*}{$\begin{array}{r}\text { RATS } \\
\text { Male }\end{array}$} & \multicolumn{4}{|c|}{ VEGETARIAN EXERCISED RATS } \\
\hline & Male & Male & Female & & Male & Female & Female & Female \\
\hline & No. I & No. 2 & No. 3 & No. 4 & No. 5 & No. 6 & No. 7 & No. 8 \\
\hline I & 200 & 3,050 & $I, 300$ & 2,060 & 2,040 & 1,180 & 760 & 2,810 \\
\hline 2 & $18,85^{\circ}$ & 26,140 & 23,010 & 23,390 & 37,120 & 26,620 & 22,550 & 49,120 \\
\hline 3 & 79,750 & 9I,I30 & I I I,320 & I 18, I 50 & 143,380 & 59,680 & 76,840 & 149,330 \\
\hline 4 & 148,460 & 189,620 & 201,730 & 248,780 & 980 & 82,070 & 133,430 & 238,940 \\
\hline 5 & 248,990 & 322,420 & 406,780 & 409,250 & 249,600 & 98,350 & 180,070 & 285,940 \\
\hline 6 & 900 & $43^{8,020}$ & 672,070 & 508,500 & 276,960 & I I I, 670 & $238,55^{\circ}$ & 364,240 \\
\hline 7 & 070 & 523,320 & $1,041,330$ & 656,470 & 314,520 & I 32,580 & 290,780 & 406,700 \\
\hline 8 & 487 & 650,490 & $1,388,260$ & 777 & & I 58,890 & 374,400 & 483,720 \\
\hline 9 & 576,360 & 786,660 & $1,678,890$ & 870,400 & & I87,9 I0 & 450,980 & 575,160 \\
\hline 10 & 722,880 & 982,210 & 2,028 , I90 & $95^{2}, 860$ & $40^{\prime}$ & 210,720 & 555 , I 80 & 659,590 \\
\hline I I & 817,000 & $\mathrm{I}, 082,000$ & $2,332,260$ & $1,039,650$ & & 224,790 & 581,180 & 694,980 \\
\hline 12 & 883, I 20 & $\mathrm{I}, 2 \mathrm{I} 5, \mathrm{I} 90$ & $2,647,640$ & $\mathrm{I}, \mathrm{IO} 4,240$ & 467,380 & 238,750 & 604,830 & 723,820 \\
\hline I3 & 961,360 & $\mathrm{I}, 378,680$ & $2,938,160$ & $1,218,620$ & 492,170 & 244,370 & 634,340 & 749,280 \\
\hline 14 & $1,068,300$ & $\mathrm{I}, 548,570$ & $3,286,540$ & $1,399,100$ & 505,820 & $\ldots$ & 651,680 & 772,930 \\
\hline I 5 & $I, I 65,990$ & $1,666,150$ & $3,559,830$ & $I, 389,440$ & 340 & & 686,590 & 784,740 \\
\hline 16 & I,206,980 & $1,760,900$ & $3,820,590$ & $I, 455,930$ & 30 & & 704,900 & 787,450 \\
\hline I7 & $1,271,700$ & $1,849,340$ & $4,091,400$ & $1,488,930$ & 520,910 & & & 790,040 \\
\hline I8 & $1,309,080$ & $\mathrm{I}, 975, \mathrm{I} 4 \mathrm{O}$ & $4,318,780$ & $1,529,400$ & 523,000 & & & 792,390 \\
\hline I9 & $1,339,080$ & $2,072,520$ & $4,599,500$ & $\mathrm{I}, 57 \mathrm{I}, 080$ & 525,890 & & & 793,620 \\
\hline 20 & $1,382,130$ & $2,146,720$ & $4,867,910$ & $1,588,7$ 10 & 527,520 & & & 794,930 \\
\hline $2 I$ & $1,400,500$ & $2,203,380$ & $5,076,100$ & $1,601,920$ & 529,160 & & & 796,360 \\
\hline 22 & I, 429,570 & $2,277,120$ & $5,290,770$ & $1,613,700$ & 530,560 & & & 797,570 \\
\hline 23 & $1,457,500$ & $2,334,160$ & $5,462,560$ & $1,624,420$ & 533,000 & & & 799,040 \\
\hline 24 & $1,469,340$ & $2,380,260$ & $5,573,480$ & $1,631,780$ & $\ldots$ & $\ldots$ & $\ldots$ & \\
\hline 25 & $\mathrm{I}, 486,250$ & $2,423,250$ & $5,679,360$ & $1,639,060$ & & & & \\
\hline 26 & ..... & $2,447,180$ & $5,796,630$ & $1,642,100$ & .. & & & \\
\hline 27 & ..... & $2,456,190$ & $5,909,860$ & $1,642,580$ & .. & & & . \\
\hline 20 & $\ldots .$. & $2,460,1$ IO & $6,018,140$ & ...... & . & & & $\ldots$ \\
\hline 29 & ...... & $2,462,520$ & $6,118,320$ & $\ldots \ldots$ & . & & & $\ldots$ \\
\hline 30 & ...... & $2,463,950$ & $6,202,570$ & ..... & $\ldots$ & & & . \\
\hline $3 I$ & ...... & $2,464,770$ & $6,259,910$ & $\ldots \ldots$ & $\ldots$ & & & $\ldots$ \\
\hline 32 & ...... & $2,465,130$ & $6,353,920$ & ...... & $\ldots$ & & & \\
\hline 33 & ...... & & $6,414,900$ & ...... & $\ldots$ & . & & \\
\hline 34 & ...... & & $6,427,500$ & ...... & ... & .. & & \\
\hline
\end{tabular}

TABLE III.-Comparative number of revolutions made by the omnivorous and vegetarian rats at the ages indicated. The number of revolutions represents the amount of voluntary running or work of each rat. 
number of revolutions which each of the exercised rats voluntarily made during its lifetime.

Table III represents the total number of revolutions of each rat at the ages indicated. To give a better idea of the amount of work equivalent to these revolutions, the actual distance in miles has been computed and shown in Table IV. By consulting these tables it is

\begin{tabular}{|c|c|c|c|c|c|c|c|c|}
\hline \multicolumn{5}{|c|}{ OMNIVOROUS EXERCISED RATS } & \multicolumn{4}{|c|}{ VEGETARIAN EXERCISED RATS } \\
\hline Age & Male & Male & Female & Male & Male & Female & Female & Female \\
\hline & No. I & No. 2 & No. 3 & No. 4 & No. 5 & No. 6 & No. 7 & No. 8 \\
\hline I & I & 2.6 & I.8 & 1.7 & I.7 & I & .6 & 2.4 \\
\hline 2 & I6 & 22 & I9 & I9.6 & $3 I .5$ & 22.6 & I9.I & 41.7 \\
\hline 3 & 68 & 77 & 95 & IOO & 122 & 50.6 & 65 & I26.6 \\
\hline 4 & I 21 & I60 & I70 & 210 & I68 & 67.6 & II 3 & 202.5 \\
\hline 5 & $2 \mathrm{II}$ & 273 & 336 & 346 & $2 \mathrm{II}$ & 83.4 & I 53 & 242 \\
\hline 6 & 278 & 373 & 572 & 495 & 234 & 94.7 & 200 & 309 \\
\hline 7 & $34 \mathrm{I}$ & 434 & 882 & 555 & 257 & I I 2.4 & 246.5 & 345 \\
\hline 8 & 4I 4 & $55 \mathrm{I}$ & I I 8 I & 658 & 297 & I34.7 & $3^{17} 7 \cdot 3$ & 410 \\
\hline 9 & 487 & 663 & I4435 & 740 & 305 & I59 & 382 & 487.5 \\
\hline IO & 612 & 832 & I7IO & 810 & 345 & 187 & 470.5 & 559 \\
\hline II & 691 & 915 & I980 & 876 & 370 & I90.5 & 492.6 & 589 \\
\hline I2 & 749 & 1023 & 2230 & 945 & 396 & 202.3 & 508.3 & 613 \\
\hline I3 & 812 & I I 55 & 2490 & 1036 & 4I7 & 207 & 537.7 & 635 \\
\hline I4 & 900 & I318 & 2780 & III 5 & 428.6 & $\ldots$ & $55^{2}$ & 655 \\
\hline I5 & 986 & I390 & 3020 & I I68 & 433.4 & $\ldots$ & $5^{81.9}$ & 665 \\
\hline I6 & 1020 & I 490 & 3230 & I 220 & 436.5 & $\ldots$ & 592.3 & 667 \\
\hline I7 & I080 & I 560 & 3460 & I270 & 440.6 & $\ldots$ & $\ldots$ & 669.6 \\
\hline I8 & IIIO & I665 & $365^{\circ}$ & I298 & 444.7 & $\ldots$ & $\ldots$ & 671.5 \\
\hline 19 & I I25 & I747 & 3890 & I325 & $445 \cdot 7$ & $\ldots$ & $\ldots$ & 672.6 \\
\hline 20 & I I65 & I850 & $4 \mathrm{I} 25$ & I347 & 447 & $\ldots$ & $\ldots$ & 673.7 \\
\hline 2 I & I I88 & I862 & 4280 & I358 & 448.5 & $\ldots$ & $\ldots$ & 675 \\
\hline 22 & I2IO & I920 & 4475 & I 362 & 449.7 & ... & ... & 676 \\
\hline 23 & 1225 & I980 & 4620 & I380 & 450.9 & $\ldots$ & $\ldots$ & 677.1 \\
\hline 24 & 1244 & 2025 & 4720 & I385 & $\ldots$ & $\ldots$ & $\ldots$ & $\ldots$ \\
\hline 25 & 1265 & 2050 & 4810 & I389 & $\ldots$ & $\ldots$ & $\ldots$ & $\ldots$ \\
\hline 26 & $\ldots$ & 2074 & 4900 & I39I & $\ldots$ & $\ldots$ & $\ldots$ & $\ldots$ \\
\hline 27 & $\ldots$ & 2090 & 5000 & $\ldots$ & $\cdots$ & ... & $\ldots$ & $\ldots$ \\
\hline 28 & $\ldots$ & 2093 & 5100 & $\ldots$ & $\cdots$ & ... & $\ldots$ & $\ldots$ \\
\hline 29 & $\ldots$ & 2095.6 & 5180 & $\ldots \ldots$ & $\cdots$ & $\ldots$ & $\ldots$ & $\ldots$ \\
\hline 30 & $\ldots$ & 2097 & 5250 & $\cdots \cdots$ & $\cdots$ & $\cdots$ & $\cdots$ & $\cdots$ \\
\hline $3^{I}$ & $\ldots$ & 2097.7 & 5300 & $\cdots$ & $\cdots$ & $\cdots$ & ... & ... \\
\hline 32 & ... & 2098 & $535^{\circ}$ & $\cdots \cdots$ & $\ldots$ & $\cdots$ & $\cdots$ & $\cdots$ \\
\hline 33 & $\cdots$ & $\ldots \ldots$ & 5430 & $\cdots \cdots$ & $\cdots$ & $\cdots$ & $\cdots$ & ... \\
\hline 34 & $\ldots$ & $\ldots \ldots$ & 5447 & .... & - . . & ... & .... & ... \\
\hline
\end{tabular}

TABLE IV.-Comparative number of miles run by the omnivorous and vegetarian rats in the revolving cages at the ages indicated. 
readily seen that the work done by all the rats corresponds rather closely during the first three or four months. This corresponds closely to the average daily work shown in Figure II. As a matter of fact the vegetarians average a trifle more at the end of the third month than

\begin{tabular}{|c|c|c|c|c|c|c|c|c|}
\hline \multirow[b]{3}{*}{$\begin{array}{c}\text { Age } \\
\text { in } \\
\text { Mos. }\end{array}$} & \multicolumn{4}{|c|}{ Average number of revolutions } & \multicolumn{4}{|c|}{ Average number of miles } \\
\hline & \multicolumn{2}{|c|}{ Omnivorous } & \multicolumn{2}{|c|}{ Vegetarian } & \multicolumn{2}{|c|}{ Omnivorous } & \multicolumn{2}{|c|}{ Vegetarian } \\
\hline & $\begin{array}{c}\text { Males } \\
\text { Avg. of } \\
3\end{array}$ & $\begin{array}{c}\text { Female } \\
\text { Avg. of } \\
\text { I }\end{array}$ & $\begin{array}{c}\text { Male } \\
\text { Avg. of } \\
\text { I }\end{array}$ & $\begin{array}{c}\text { Female } \\
\text { Avg. of } \\
3\end{array}$ & $\begin{array}{c}\text { Male } \\
\text { Avg. of } \\
3\end{array}$ & $\begin{array}{c}\text { Female } \\
\text { Avg. of } \\
I\end{array}$ & $\begin{array}{c}\text { Male } \\
\text { Av of } \\
\text { I }\end{array}$ & $\begin{array}{l}\text { Female } \\
\text { Avg. of } \\
3 \\
\end{array}$ \\
\hline I & $2, \mathrm{IO} 3$ & 1,300 & 2,040 & $\mathrm{I}, 583$ & I.8 & I. 8 & I.7 & I.3 \\
\hline 2 & 22,793 & 23,OIO & 37,120 & 783 & I9.2 & I9. & $3 \mathrm{~T} .5$ & 27.5 \\
\hline 3 & 95,343 & 320 & I 43,380 & 93,283 & 82. & 95. & I22. & 80.7 \\
\hline 4 & 620 & 201 & 198,980 & 131,480 & I64. & I70. & I68. & 127.7 \\
\hline 2 &, 887 & 406,780 & 249,600 & I3 & 277 . & 336. & $2 \mathrm{II}$. & 9.5 \\
\hline 6 & 473 & 672,070 & 276,960 & 2 & 349. & 572. & 234. & OI.I \\
\hline 7 &, 620 & $\mathrm{I}, \mathrm{O}$ & 14,220 & 3 & 443. & 882. & 257. & 234.6 \\
\hline 8 &, 420 & I, & 0 & & $54 \mathrm{I}$. & I I 8 I. & 297. & 287.7 \\
\hline 9 & 473 &, 890 & 382,320 & 40 & 630. & I 435. & 305. & 34 \\
\hline IO & 983 & 8,190 & 407, & 47 & 751. & o. & 345. & .5 \\
\hline II & 979,550 & 260 & 4.37 & & 827. & 3o. & 370. & 424.3 \\
\hline I2 & $1,067,517$ & $2,647,640$ & 467,380 & 522,467 & 906. & 2230. & 396. & $44 \mathrm{I}$. \\
\hline 13 & 6,220 & $2,938,160$ & $492, \mathrm{x} 70$ & 542,663 & IOOI. & 2490. & 417. & 470. \\
\hline I4 & 8,657 & $3,286,540$ & 505,820 & 327 & I I I I. & o. & 428.6 & 471.3 \\
\hline I5 & 7,193 & 9,830 & $5 \mathrm{II}, 340$ & 57 & II 8I. & 3020. & 433.4 & 482.6 \\
\hline I6 & $1,474,603$ & $3,820,590$ & $515,5,30$ & 578,907 & I 243. & 3230. & 436.5 & 488.8 \\
\hline 17 & $\mathrm{I}, 536,670$ & $4,091,400$ & 520,910 & 770 & I 303. & 3460. & 440.6 & 486.6 \\
\hline I 8 & $1,604,540$ & $4,318,780$ & 523,000 & 580,553 & I.338. & 3650. & 444.7 & 490.3 \\
\hline I9 & I,660,893 & 9,500 & 525,890 & 580,763 & I.399. & 3890. & 445.7 & 490.6 \\
\hline 20 & $1,705,853$ & $4,867,910$ & 527,520 & $58 \mathrm{I}, 400$ & I 454. & 4125. & 447. & 491. \\
\hline $2 \mathrm{I}$ & $1,735,267$ & $5,076,100$ & 529, І6о & 581,877 & I469. & 4280. & 448.5 & 491.4 \\
\hline 22 & $1,773,463$ & 770 & 530,560 & 582,280 & I 497. & 4475 & 449.7 & 491.8 \\
\hline 23 & $1,805,327$ & $5,462,560$ & 533,000 & 582,770 & I 528. & 4620. & 450.9 & 492.I \\
\hline 24 & $1,827,127$ & 3,480 & $\ldots$ & $\ldots$ & $15.5 \mathrm{I}$. & 4720. & . & . \\
\hline 25 & 99,520 & 0 & $\cdots$ & & I 568. & 48ro. & $\cdots$ & $\cdots$ \\
\hline 26 & 3,510 & 6,630 & $\ldots$ & . & I 577. & 4900. & $\ldots$ & $\ldots$ \\
\hline 27 & г,86г,673 & 860 & $\ldots$ & & I 582. & 5000. & $\ldots$ & $\ldots$ \\
\hline 28 & 2,980 & 0 & $\cdots$ & & I 583. & & $\cdots$ & $\ldots$ \\
\hline 29 & 3,450 & 6 , & $\cdots$ & & 7.2 & o. & $\ldots$ & .. \\
\hline $3 c$ & 54,220 & 6,20 & $\ldots$ & • & I 587.7 & 5250. & $\ldots$ & $\ldots$ \\
\hline 3 &, 533 & 6,25 & $\ldots$ & & I 587.9 & o. & $\cdots$ & $\ldots$ \\
\hline $3^{2}$ & I,864,653 & & $\cdots$ & & I 588. & & $\cdots$ & $\ldots$ \\
\hline 33 & & & $\cdots$ & .. & & O. & $\cdots$ & $\ldots$ \\
\hline 24 & & 27.50 & & & & & & \\
\hline
\end{tabular}

TABLE V.-Showing the relative amount of work done by the two classes of animals in revolving cages as indicated by the average number of revolutions and the average distance run at the different ages. 
the omnivorous. This is seen by consulting Table $\mathrm{V}$, which represents the averages of each sex of these two groups.

From this I think one of two conclusions may be reached. Either the sudden reduction in the rich protein food of the omnivorous rats to almost a vegetarian diet (meat being given only two or three times a week) has had the effect of checking the activity of all alike, or a strictly vegetarian diet at this age is conducive to a slightly greater activity. If the latter is true it may be explained in this manner: The omnivorous rat had a satisfying diet; the vegetarians did not, and ran

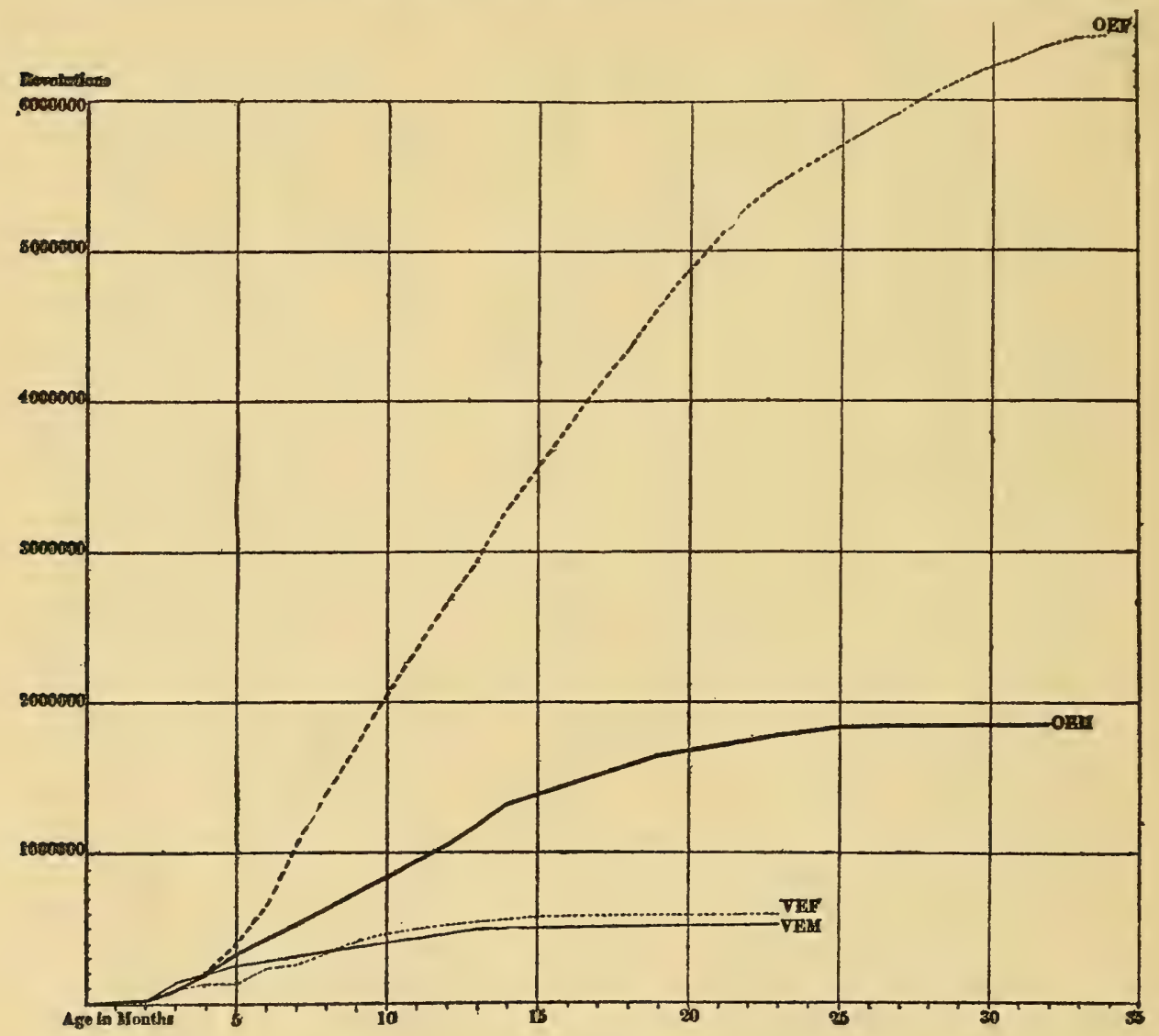

Fig. I2. Curves showing the average total work and the rate it was done of each sex of exercised omnivorous and vegetarian feeders. The heavy solid line $(O E M)$ represents the work of the omnivorous males, the heavy dotted line $(O E F)$ the omnivorous females; the light solid line $(V E M)$ the vegetarian males, the light dotted line $(V E F)$ the vegetarian females. 
a great deal, apparently in search for what they desired. The behavior of the vegetarians strongly supports this supposition. When they were fed they ate ravenously, as if they had been starving. This was not so manifest in the omnivorous. It was true that both classes of exercised rats always appeared more hungry than the control rats of the same group.

After the third month the general average of the vegetarians falls below that of the omnivorous. This is shown in the curves of Figure I2. Here we see that the omnivorous female rapidly surpasses the omnivorous male in the amount of work done. The female vegetarian also excels the male of the same class in the distance run, but only to a small extent. The females are thus voluntarily more active than the males. We also note that the omnivorous male is much more active than either sex of the vegetarians. At the time of the death of the vegetarian rats (twenty-five months) the omnivorous female had voluntarily done almost nine and one-half times as much work as the female vegetarian, and the omnivorous male almost three and one-half times as much as the male vegetarian.

When the total amount of work voluntarily done by each class is considered, a still greater difference is observed. The omnivorous female ran a total distance of 5447 miles, while the vegetarian female ran only 492.I miles, or a ratio of about II : $I$. The omnivorous male ran I588 miles, compared to 450.9 miles for the vegetarian male-a ratio of $3.5: \mathrm{I}$. The average run for both sexes was, for the omnivorous rats 35 I 7.5 miles, and for the vegetarians 471.5 miles, or a ratio of almost $7 \cdot 5: 1$.

We thus see that when the initiative and ability to do work are considered, the result is decidedly in favor of the rats that had received animal food in their diet, and overwhelmingly against the vegetarians.

The curves of Figure I2 show in a general way the rate at which the life's work was accomplished by each rat. But to show this more clearly Table VI has been constructed. The total average work for each sex in the two groups was arbitrarily divided into eight equal parts. Then the per cent of average lifetime required to do these fractional parts was computed; also the average age in months equivalent to this per cent is given. For example, when the omnivorous male had done one-eighth of its total life's work it had lived I6.I\% of its average lifetime, and had reached the average age of 4.5 months. This table shows that the males of each group turn off their work at a relatively earlier age than the females on the same diet. As an illustration, when the omnivorous male had done one-half its life work it had lived $36.4 \%$ 
of its life, while the omnivorous female had lived $4 \mathrm{I} \%$ of its life when it had accomplished a similar part of its total work. A similar relation is seen to exist between the two sexes of the vegetarians. We also see that the same fractional part of total work is accomplished at an

\begin{tabular}{|c|c|c|c|c|c|c|c|c|c|}
\hline \multicolumn{3}{|c|}{$\begin{array}{c}\text { Fractional part of total amount of } \\
\text { life's work }\end{array}$} & $\mathrm{T} / 8$ & $\mathrm{~T} / 4$ & $3 / 8$ & $1 / 2$ & $5 / 8$ & $3 / 4$ & $7 / 8$ \\
\hline \multirow{2}{*}{ 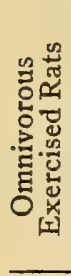 } & Males (.3).. & $\begin{array}{l}\text { Percentage of life re- } \\
\text { quired to do work. } \\
\text { Age in months re- } \\
\text { quired to do work. }\end{array}$ & $\begin{array}{r}\text { I6.I } \\
4.5\end{array}$ & $\begin{array}{c}2 \mathrm{I} .4 \\
6 .\end{array}$ & $\begin{array}{c}32.1 \\
9 .\end{array}$ & $\begin{array}{l}36.4 \\
10.2\end{array}$ & $\begin{array}{l}46.4 \\
\text { I3. }\end{array}$ & $\begin{array}{l}53.8 \\
\text { I } 5 .\end{array}$ & $\begin{array}{l}67.9 \\
18 .\end{array}$ \\
\hline & $\overline{\text { Female (I) }}$ & $\begin{array}{l}\text { Percentage of life re- } \\
\text { quired to do work. } \\
\text { Age in months re- } \\
\text { quired to do work. }\end{array}$ & $\begin{array}{r}\text { I9.I } \\
6.5\end{array}$ & $\begin{array}{r}26.1 \\
8.9\end{array}$ & $\begin{array}{l}32.3 \\
\text { II.I }\end{array}$ & $\begin{array}{l}4 \mathrm{I} . \\
\text { I } 3.8\end{array}$ & $\begin{array}{l}48.8 \\
16.6\end{array}$ & $\begin{array}{l}53.8 \\
19.9\end{array}$ & $\begin{array}{l}72.6 \\
24.7\end{array}$ \\
\hline \multirow{2}{*}{ 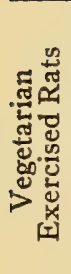 } & Male & $\begin{array}{l}\text { Percentage of life re- } \\
\text { quired to do work. } \\
\text { Age in months re- } \\
\text { quired to do work.. }\end{array}$ & $\begin{array}{l}\text { IO. } \\
2.3\end{array}$ & $\begin{array}{r}12.3 \\
2.8\end{array}$ & $\begin{array}{c}17.6 \\
4 .\end{array}$ & $\begin{array}{r}24.1 \\
5.5\end{array}$ & $\begin{array}{r}32.8 \\
7.5\end{array}$ & $\begin{array}{r}41.6 \\
9.5\end{array}$ & $\begin{array}{l}51.7 \\
\text { II. }\end{array}$ \\
\hline & Females (.3) & $\begin{array}{l}\text { Percentage of life re- } \\
\text { quired to do work. } \\
\text { Age in months re- } \\
\text { quired to do work. }\end{array}$ & $\begin{array}{r}\text { I } 5.9 \\
2.7\end{array}$ & $\begin{array}{r}22.5 \\
3.8\end{array}$ & $\begin{array}{r}31.9 \\
5.4\end{array}$ & $\begin{array}{r}42.5 \\
7.2\end{array}$ & $\begin{array}{c}49 . \\
8.3\end{array}$ & $\begin{array}{r}53.3 \\
9.1\end{array}$ & $\begin{array}{l}66.1 \\
\text { II. } 2\end{array}$ \\
\hline
\end{tabular}

TABLE VI-Comparison of omnivorous and vegetarian rats as to the rate of doing their life's work.

earlier age in the males than in the females of the same class, with the exception of the last two items in the vegetarian group: here the male is very slightly surpassed by the female. This shows that the male ages earlier than the female. That is, when the male has begun to be inactive the female of the same age is still quite active.

We further see that the vegetarians do the bulk of their work at an earlier age than the omnivorous rats. That is, they become old, decrepit, lack energy and a desire to be active at an earlier age than is true in the case of the omnivorous rats. This is true both as to percentage of life lived and age in months. For example, when the omnivorous rats had done seven-eighths of their total work the males had lived $67.9 \%$ of their life and the females $72.6 \%$, the two sexes averaging $70 \%$. In the case of the vegetarians the males had lived $51.7 \%$ and the females $66.1 \%$, or an average for the two sexes of $59 \%$. We thus see that the vegetarians had still an average of $4 \mathrm{I} \%$ of their lives to live, during which time they did only one-eighth of their work. The omnivorous had an average of $30 \%$ to live to do the remaining oneeighth of their total work. 
We have already shown that the ratio of total average work done by the omnivorous rats as compared to that of the vegetarians was about as 7.5 : I. To make allowance for this, Table VII was constructed. This shows the percentage of lifetime of the omnivorous rats and their age in months which was required to do certain fractional parts of the total work of the vegetarians. That is, the two groups are considered in respect to their ability to perform the same amount of work. The data of the vegetarians is therefore the same in this table as in Table VI. From this we see that the average ages in months of the two classes correspond rather closely until three-eighths of their work was done. After this the ages rapidly differ. When the vegetarian male died it was 22.8 months old. The omnivorous male had accomplished the same amount of work when it was but 6.9 months old and had lived but $22.5 \%$ of its life. The female vegetarian died at the average age of I6.9 months. In contrast, the omnivorous female had done the same amount of work at the age of 5.6 months, which was equivalent to but $16.6 \%$ of its lifetime. Or the average total amount of work of both sexes of vegetarians was performed at the average age of I9.8 months,- that is, their average lifetime. Both sexes of the omnivorous feeders had done the same work at the average age of 6.2 months, which was but $20.9 \%$ of their lifetime.

\begin{tabular}{|c|c|c|c|c|c|c|c|c|c|c|}
\hline \multicolumn{3}{|c|}{$\begin{array}{c}\text { Fractional part of total amount of } \\
\text { life's work }\end{array}$} & $1 / 8$ & $\mathrm{I} / 4$ & $3 / 8$ & $1 / 2$ & $5 / 8$ & $3 / 4$ & $7 / 8$ & $8 / 8$ \\
\hline \multirow{2}{*}{ 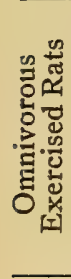 } & $\overline{\text { Males (.3)... }}$ & $\begin{array}{l}\text { Percentage of life re- } \\
\text { quired to do work. } \\
\text { Age in months re- } \\
\text { quired to do work. }\end{array}$ & $\begin{array}{l}9.8 \\
2.7\end{array}$ & $\begin{array}{r}\text { I3.8 } \\
3.8\end{array}$ & $\begin{array}{c}14.6 \\
4 .\end{array}$ & $\begin{array}{r}15.7 \\
4.3\end{array}$ & $\begin{array}{c}18.3 \\
5 .\end{array}$ & $\begin{array}{r}20.5 \\
5.6\end{array}$ & $\begin{array}{r}22.5 \\
6.2\end{array}$ & $\begin{array}{r}25.2 \\
6.9\end{array}$ \\
\hline & $\overline{\text { Female (I). }}$ & $\begin{array}{l}\text { Percentage of life re- } \\
\text { quired to do work.. } \\
\text { Age in months re- } \\
\text { quired to do work.. }\end{array}$ & $\begin{array}{l}8.2 \\
2.8\end{array}$ & $\begin{array}{r}10.5 \\
3.6\end{array}$ & $\begin{array}{c}10.9 \\
4 .\end{array}$ & 12.7 & $\begin{array}{r}\text { I3.6 } \\
4.6\end{array}$ & $\begin{array}{c}14.7 \\
5 .\end{array}$ & $\begin{array}{r}\text { I } 5.7 \\
5.3\end{array}$ & $\begin{array}{r}16.6 \\
5.6\end{array}$ \\
\hline \multirow{2}{*}{ 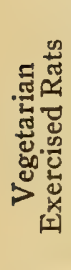 } & $\mathrm{Ma}$ & $\begin{array}{l}\text { Percentage of life re- } \\
\text { quired to do work.. } \\
\text { Age in months re- } \\
\text { quired to do work. }\end{array}$ & $\begin{array}{l}\text { IO. } \\
2.3\end{array}$ & $\begin{array}{r}\text { I } 2.3 \\
2.8\end{array}$ & $\begin{array}{c}17.6 \\
4 .\end{array}$ & $\begin{array}{r}24 . I \\
5.5\end{array}$ & $\begin{array}{r}32.8 \\
7.5\end{array}$ & $\begin{array}{r}41.6 \\
9.5\end{array}$ & $\begin{array}{l}5 \mathrm{I} .7 \\
\mathrm{II} .8\end{array}$ & $\begin{array}{l}100 . \\
22.8\end{array}$ \\
\hline & Females (3) & $\begin{array}{l}\text { Percentage of life re- } \\
\text { quired to do work. } \\
\text { Age in months re- } \\
\text { quired to do work.. }\end{array}$ & $\begin{array}{r}\text { I } 5.9 \\
2.7\end{array}$ & $\begin{array}{r}22.5 \\
3.8\end{array}$ & \begin{tabular}{|r|}
31.9 \\
5.4
\end{tabular} & $\left|\begin{array}{r}42.5 \\
7.2\end{array}\right|$ & $\begin{array}{r}49 . \\
8.3\end{array}$ & $\begin{array}{r}53.3 \\
9.1\end{array}$ & $\begin{array}{l}66.1 \\
\text { I I. } .2\end{array}$ & $\begin{array}{l}100 . \\
16.9\end{array}$ \\
\hline
\end{tabular}

TABLE VII.-Showing percentage of whole lifetime of omnivorous rats required to accomplish the same work as that performed by the vegetarian rats during the whole of their lifetime. 
We thus have the same amount of work done by the two classes. The vegetarians required 19.8 months, or the whole of their lifetime, while the omnivorous needed only $20.9 \%$ of their lifetime, and averaged 6.2 months of age. Thus the ratio of omnivorous to the vegetarians in regard to efficiency would be $100: 20.9$, or about $5: \mathrm{I}$. We must not lose sight of the fact that this difference in ability to do work is caused by the presence of animal food in one diet and the absence of it in the other, this being the only difference in the environment.

If a table were made comparing the amount of work done by each class at the same average age, the difference would be more marked than just shown. It is not considered necessary to construct such a table.

\section{GROWTH.}

We have just considered what a marked effect on the efficiency of the rat these two diets had. Let us now consider the effect on growth.

The rats were weighed before feeding about once each two weeks. Weighings made approximately a month apart were selected in making Table VIII. This shows the individual weights of each of the sixteen rats at intervals of about a month during their entire lifetime. The young at the age of thirty days thus appear to be nearly uniform in size. The advantage is slightly in favor of the vegetarians, the males averaging 42 grams and the females 39 grams, while the omnivorous male averaged $4 \mathrm{I}$ grams and the female 38 grams. Twenty-eight days later, when the two groups were put on the omnivorous and vegetable diets, the sexes averaged approximately the same. Eleven days later a difference in the rate of growth is already noticed. This is more obvious in Table IX, which represents the averages of each sex in the different groups. As the rats became older this difference in weight was more and more noticeable, becoming greater as age advanced.

It was previously noted ${ }^{2}$ that the control rats surpassed the exercised ones in weight. The same is observed here in both groups of rats. This is especially noticeable in the curves of Figure I3, which represent the data of Table IX. The heavy lines are the averages of the omnivorous rats, the light lines the vegetarians. The male in each case is decidedly heavier than the female of the same group. Also the control and exercised males excel both the control and exercised females of the omnivorous group. This relation does not exist in the vegetarian. The heaviest omnivorous female exceeds the heaviest vegetarian male by 9 grams and the heaviest vegetarian female by 36 grams. The maximum weight in each of these tables is shown in bold type. 


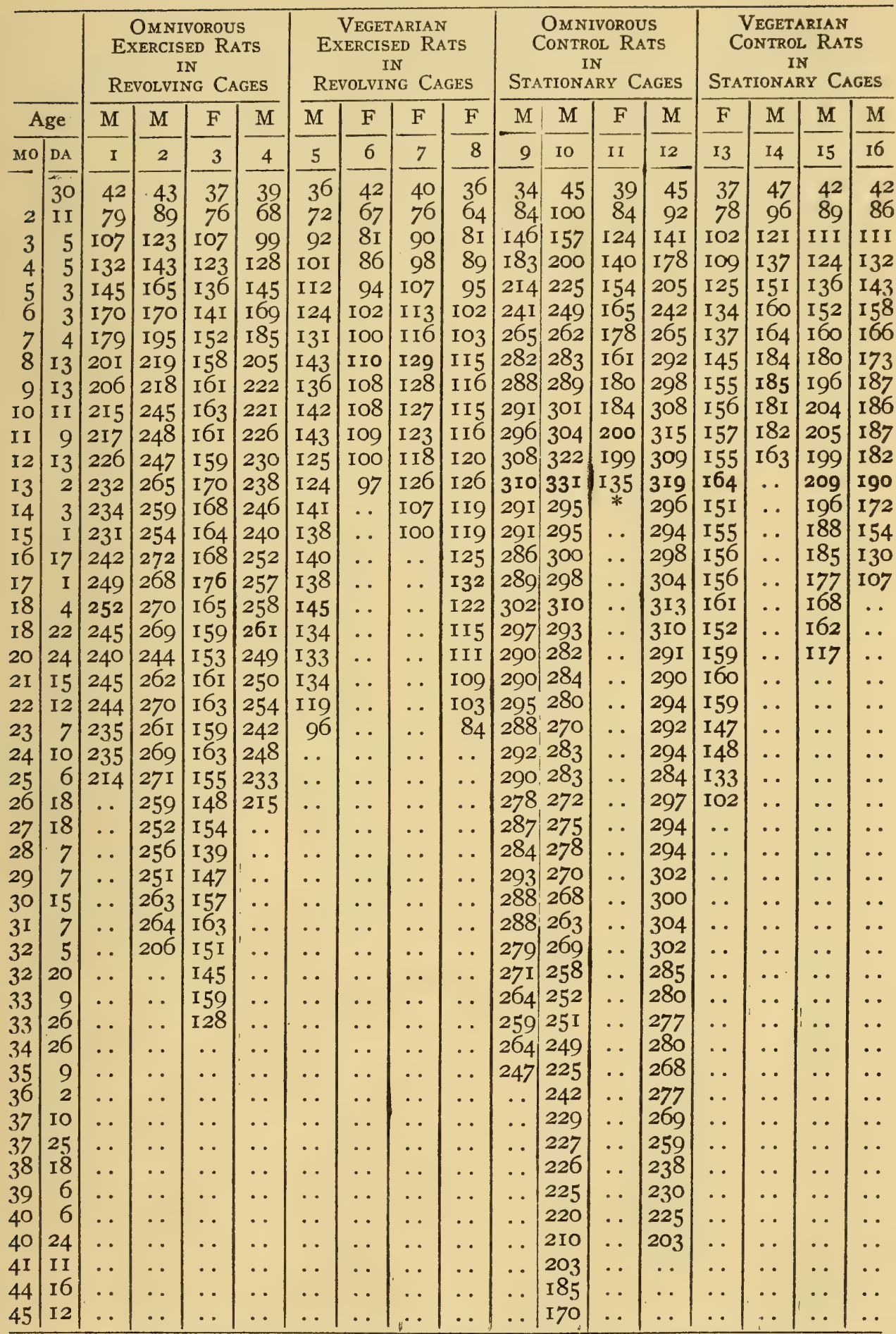

TABLE VIII.-Showing rate of growth of the different groups of rats at the ages indicated. The bold figures indicate the maximum weights. Weights are in grams.

* Was killed on account of sickness. 


\begin{tabular}{|c|c|c|c|c|c|c|c|c|}
\hline \multirow[b]{2}{*}{$\begin{array}{l}\text { Age in } \\
\text { Months }\end{array}$} & \multicolumn{2}{|c|}{$\begin{array}{c}\text { OMNIVOROUS } \\
\text { EXERCISED RATS }\end{array}$} & \multicolumn{2}{|c|}{$\begin{array}{c}\text { VEGETARIAN } \\
\text { EXERCISED RATS }\end{array}$} & \multicolumn{2}{|c|}{$\begin{array}{l}\text { OMNIVOROUS } \\
\text { CONTROL RATS }\end{array}$} & \multicolumn{2}{|c|}{$\begin{array}{c}\text { VeGETARIAN } \\
\text { CoNTROL Rats } \\
\end{array}$} \\
\hline & $\begin{array}{l}\text { Male } \\
\text { (Av. 3) }\end{array}$ & $\begin{array}{l}\text { Female } \\
\text { (Av. I) }\end{array}$ & $\begin{array}{l}\text { Male } \\
(\mathrm{Av} . I)\end{array}$ & $\begin{array}{l}\text { Female } \\
\text { (Av. 3) }\end{array}$ & $\begin{array}{c}\text { Male } \\
(\text { Av. 3) }\end{array}$ & $\begin{array}{l}\text { Female } \\
\text { (Av. r) }\end{array}$ & $\begin{array}{l}\text { Male } \\
\text { (Av. 3) }\end{array}$ & $\begin{array}{l}\text { Female } \\
\text { (Av. I) }\end{array}$ \\
\hline $\begin{array}{l}I . \\
2.4\end{array}$ & $\begin{array}{l}4 \mathrm{I} \\
79\end{array}$ & $\begin{array}{l}37 \\
76\end{array}$ & $\begin{array}{l}36 \\
72\end{array}$ & $\begin{array}{l}39 \\
69\end{array}$ & $\begin{array}{l}4 I \\
92\end{array}$ & $\begin{array}{l}39 \\
84\end{array}$ & $\begin{array}{l}44 \\
90\end{array}$ & $\begin{array}{l}37 \\
78\end{array}$ \\
\hline 3.2 & IIO & IO7 & 92 & 84 & $\begin{array}{r}148\end{array}$ & $\begin{array}{r}124 \\
\text { I }\end{array}$ & II 4 & IO2 \\
\hline 4.2 & I34 & 123 & IOI & $9 \mathrm{I}$ & I87 & 140 & I3I & rog \\
\hline 5.1 & I 52 & I36 & I 12 & 99 & 215 & I54 & I 43 & 125 \\
\hline 6.I & I7O & I $4 \mathrm{I}$ & 124 & 106 & 244 & 165 & I 57 & I34 \\
\hline 7.1 & I86 & I 52 & I3I & I06 & 264 & 178 & I63 & I 37 \\
\hline 8.4 & 208 & I 58 & I 43 & II7 & 286 & $16 \mathrm{I}$ & I79 & I 45 \\
\hline 9.4 & $2 \mathrm{I} 5$ & $16 I$ & I36 & II 8 & 292 & I80 & I89 & I55 \\
\hline I0.4 & 227 & I63 & I 42 & II 7 & 300 & I84 & I9O & I56 \\
\hline II. 3 & 230 & I6I & I 43 & II7 & 305 & 200 & I9I & I 57 \\
\hline I2.I & 234 & I 59 & 125 & II3 & 3I 3 & I99 & $\mathrm{I} 8 \mathrm{I}$ & I 55 \\
\hline I3.I & 245 & I70 & 124 & I 16 & 320 & I35 & I87 & I64 \\
\hline I4.I & 246 & 168 & I4I & I08 & 294 & & I77 & I 5 I \\
\hline I5. & 242 & I64 & I38 & IO5 & 293 & $\ldots$ & I68 & I55 \\
\hline I6.6 & 255 & 168 & I 40 & 107 & 295 & $\ldots$ & I59 & I56 \\
\hline 17. & 258 & I 76 & I38 & IIO & 297 & $\ldots$ & I 49 & I 56 \\
\hline I8.I & 260 & I65 & I 45 & I06 & 308 & $\ldots$ & 146 & I6I \\
\hline I8.7 & 258 & I 59 & I34 & IO4 & 300 & $\ldots$ & I 44 & ${ }^{1} 5^{2}$ \\
\hline 20.8 & 244 & I 53 & I33 & IO3 & 288 & $\ldots$ & I29 & I59 \\
\hline 21.5 & 252 & 161 & I34 & IO2 & 288 & $\ldots$ & $\ldots$ & I60 \\
\hline 22.4 & 256 & I63 & II9 & 100 & 290 & $\ldots$ & $\ldots$ & I 59 \\
\hline 23.2 & 246 & I 59 & 96 & 94 & 283 & $\ldots$ & $\ldots$ & I 47 \\
\hline $24 \cdot 3$ & $25 \mathrm{I}$ & 163 & $\ldots$ & $\ldots$ & 290 & $\ldots$ & $\ldots$ & I48 \\
\hline 25.2 & 239 & I55 & $\ldots$ & $\ldots$ & 286 & . . & $\ldots$ & I33 \\
\hline 26.6 & 228 & I 48 & $\ldots$ & $\ldots$ & 282 & ... & $\ldots$ & IO2 \\
\hline 27.6 & 227 & I 54 & $\ldots$ & ... & 285 & $\ldots$ & $\ldots$ & $\ldots$ \\
\hline 28.2 & 228 & I39 & $\ldots$ & $\ldots$ & 285 & $\ldots$ & ... & ... \\
\hline 29.2 & 227 & I47 & ... & ... & 288 & $\ldots$ & $\ldots$ & $\ldots$ \\
\hline 30.5 & $23^{\circ}$ & I 57 & ... & $\ldots$ & 285 & $\ldots$ & $\ldots$ & $\ldots$ \\
\hline $3 \mathrm{I} .2$ & $23 I$ & I63 & ... & ... & 285 & $\ldots$ & $\ldots$ & $\ldots$ \\
\hline 32.2 & 212 & I 51 & $\ldots$ & $\ldots$ & 283 & $\ldots$ & $\ldots$ & $\ldots$ \\
\hline 32.7 & ... & $\mathrm{r} 45$ & $\ldots$ & $\ldots$ & 271 & $\ldots$ & $\ldots$ & $\ldots$ \\
\hline $33 \cdot 3$ & ... & I 59 & ... & ... & 265 & $\ldots$ & $\ldots$ & $\ldots$ \\
\hline 33.9 & $\ldots$ & 128 & ... & $\ldots$ & 262 & ... & $\ldots$ & $\ldots$ \\
\hline 34.9 & $\ldots$ & $\ldots$ & ... & ... & 264 & ... & ... & ... \\
\hline $35 \cdot 3$ & $\ldots$ & . . & . . & ... & 247 & ... & ... & ... \\
\hline 36.1 & ... & ... & . & ... & 255 & ... & $\ldots$ & ... \\
\hline $37 \cdot 3$ & $\cdots$ & $\ldots$ & $\ldots$ & $\ldots$ & 248 & $\ldots$ & ... & .. \\
\hline 37.8 & $\ldots$ & $\ldots$ & $\ldots$ & $\ldots$ & 244 & $\ldots$ & $\ldots$ & $\cdots$ \\
\hline 38.6 & $\ldots$ & $\ldots$ & $\ldots$ & $\cdots$ & 237 & $\ldots$ & $\ldots$ & .. \\
\hline 39.2 & $\ldots$ & $\cdots$ & $\cdots$ & $\ldots$ & 234 & $\ldots$ & $\ldots$ & . \\
\hline 40.2 & $\ldots$ & $\ldots$ & $\cdots$ & $\ldots$ & $23 I$ & . & $\ldots$ & . \\
\hline 40.8 & $\ldots$ & $\cdots$ & $\ldots$ & $\ldots$ & 220 & $\ldots$ & $\ldots$ & $\ldots$ \\
\hline $4 \mathrm{I} .4$ & $\ldots$ & $\cdots$ & $\cdots$ & $\cdots$ & 218 & $\ldots$ & $\ldots$ & $\ldots$ \\
\hline 44.5 & $\cdots$ & $\cdots$ & $\cdots$ & $\cdots$ & $2 \mathrm{I} 2$ & $\ldots$ & $\ldots$ & $\ldots$ \\
\hline 45.4 & . & $\cdots$ & $\cdots$ & $\cdots$ & 207 & $\cdots$ & ... & $\cdots$ \\
\hline
\end{tabular}

TABLE IX.-Showing the average growth of the two sexes in the groups indicated. The maximum average weight is shown in bold type. The weights are in grams.

*This rat was killed because of sickness. 


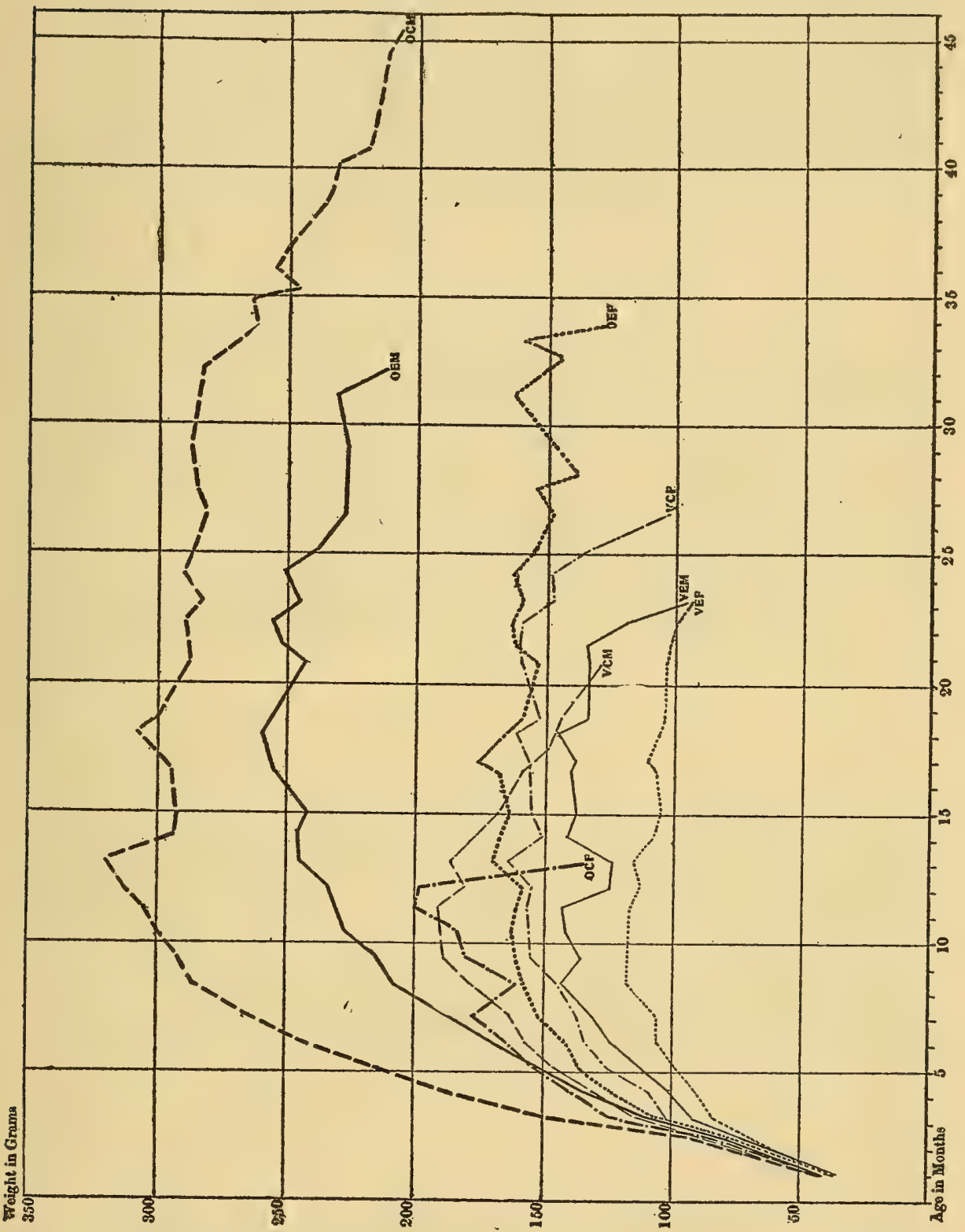

Fig. 13. Curves representing the average growth of each sex of the four groups of rats. The omnivorous feeders are all shown in heavy lines and the vegetarians in light lines. Lines of the same character refer to the same sex of similar groups. $O C M$ and $V C M$ refer to omnivorous and vegetarian control males; $O C F$ and $V C F$ represent omnivorous and vegetarian control females; $O E M$ and $V E M$, omnivorous and vegetarian exercised males; $O E F$ and $V E F$, omnivorous and vegetarian exercised females. 
A glance at Tables VIII and IX shows that, with the exception of the exercised vegetarian female, the exercised rats reach their maximum weight at an older age than the control rats, regardless of the diet. In Table $\mathrm{X}$ these facts are in a more accessible form. It shows the individual weights and the age of each rat, and the average weights and ages of each sex in each group, at the beginning of the experiment, as the maximum weight, and at death. As already stated, the average weights of the young were about as uniform as could be gotten. When the maximum weights are considered a marked contrast is noted. In every case the average weight of each sex is decidedly in favor of the omnivorous rats.

Considering the exercised rats in regard to the maximum weights and weights at death, we find the following ratios:

MAXIMUM WT. AT DEATH

Omnivorous male to vegetarian male.... I.8 : I 2.2 : I

Omnivorous females to vegetarian females I.42 : I

In regard to the control rats the following ratios were found:

MAXIMUM WT. AT DEATH

Omnivorous male to vegetarian male..... I.64 : I I.9 : I

Omnivorous female to vegetarian female.. $1.22: \mathrm{I} \quad .9: \mathrm{I}$

This last ratio is not reliable, as the control female had to be killed on account of sickness. There is no doubt had it been normal it would have reached a much heavier weight, since other omnivorous females did not reach their maximum weight until a much later age.

In regard to growth, we must conclude that the data is decidedly in favor of the omnivorous rats and against the vegetarians.

The appearance and attitude of the two groups is also in marked contrast. Figures I4, I5, I6 and I7 are photographs of eight of these rats, all being of the same age. Those on the left of each figure are omnivorous rats; those on the right are vegetarians. Figure I4 represents females. The other three figures are of males.

These photographs show the marked difference in appearance and attitude referred to above. The vegetarians were emaciated and skinny. Their back arched and more or less stiffened. The fur was harsh and ruffled, and the tail and nose inclined to be more or less covered with dry scale and sores. The attitude presented extreme lassitude and indifference. They remained in a crouched position most of the time, their legs appearing too weak to support their weight for only a short while. They lacked energy and would stay "put" when placed ready for photographing. 


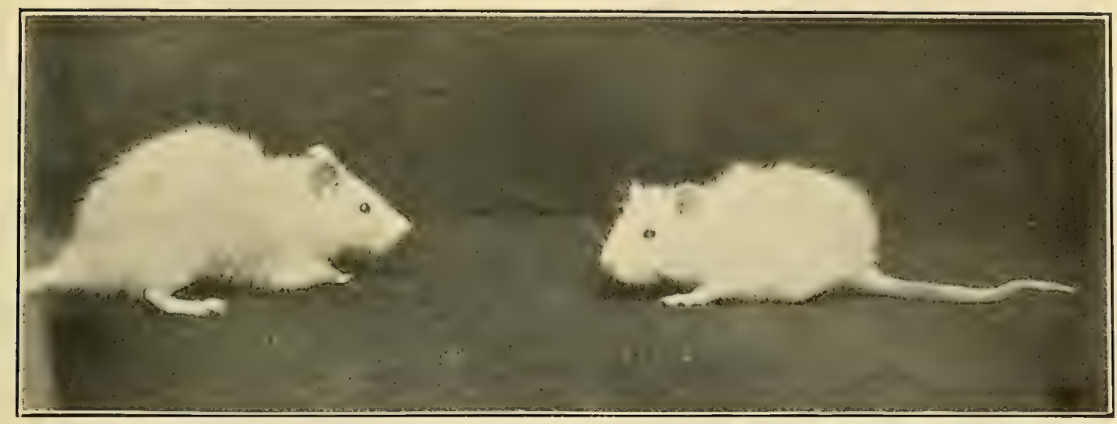

Fig. I4. Photographs of omnivorous female (left) and vegetarian female (right) at the age of $x$ year 9 months 16 days. The omnivorous weighed $16 \mathrm{I}$ grams, the vegetarian 109 grams.

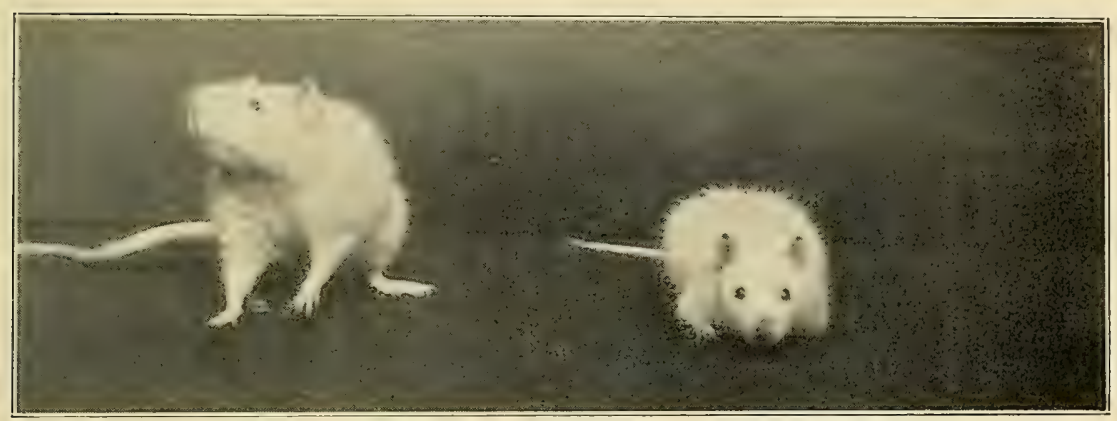

Fig. I5. Photographs of omnivorous male (left) and vegetarian male (right) at the age of I year 9 months 16 days. The omnivorous weighed 250 grams, the vegetarian $\mathbf{I} 34$ grams.

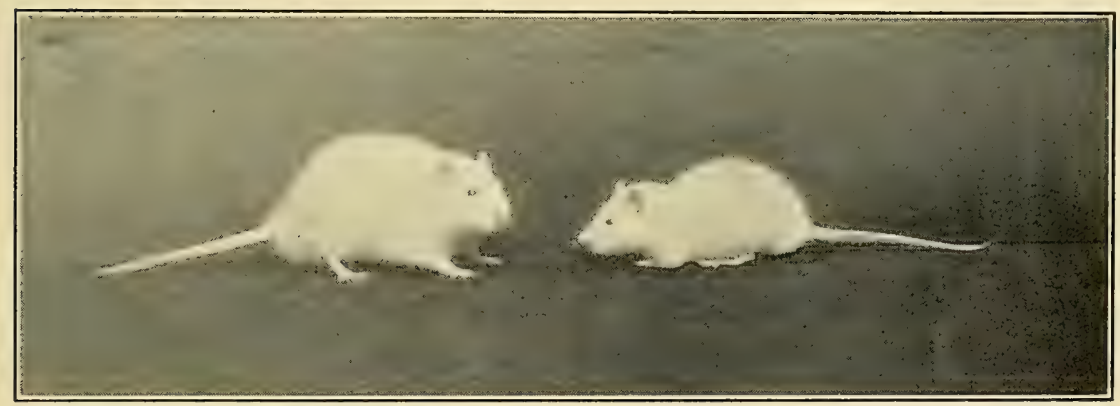

Fig. I6. Photographs of omnivorous male (left) and vegetarian male (right) at the age of I year 9 months 16 days.

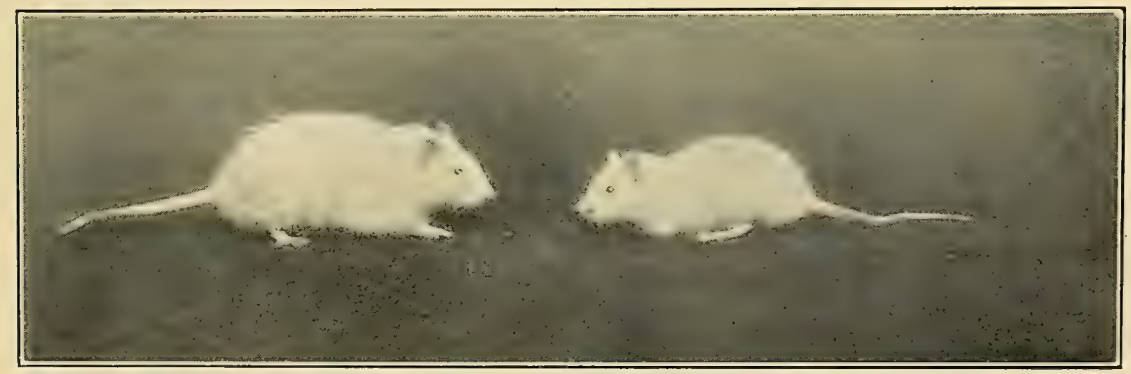

Fig. 17. Photographs of omnivorous male (left) and vegetarian male (right) at the age of I year 9 months 16 days. 

The omnivorous were the reverse in all these respects. They were strong, well nourished and supple. Their fur was soft and well kept. Tail and nose were clean and smooth. They appeared full of vim and energy, it being difficult to keep them quiet long enough to photograph. The photographs, though showing a great difference, fail to show the marked contrast one would see in a few minutes' observation of the two groups, Such an observation would demonstrate the great difference in alertness and interest in surrounding objects, quickness and ease of movement in response to external stimuli, voluntary movement and vigor. The omnivorous appeared in the prime of life in all these respects, but in the case of the vegetarians these qualities were manifested as in extreme old age.

\begin{tabular}{|c|c|c|c|c|c|c|c|c|c|c|c|c|c|c|c|c|c|c|}
\hline & \multicolumn{6}{|c|}{ Young } & \multicolumn{7}{|c|}{ At Maximum Weight } & \multicolumn{5}{|c|}{ At Death } \\
\hline & \multirow[b]{2}{*}{ 茫 } & \multirow[b]{2}{*}{$\begin{array}{l}x \\
0 \\
\tilde{n}\end{array}$} & \multirow[b]{2}{*}{$\mid \begin{array}{c}\frac{\vec{c}}{60} \\
\cdot \frac{\pi}{v} \\
3\end{array}$} & \multirow{2}{*}{ 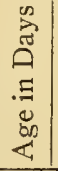 } & \multirow{2}{*}{$\left|\begin{array}{c}\infty \\
\sum_{4} \\
0 \\
\frac{3}{z}\end{array}\right|$} & \multirow{2}{*}{ 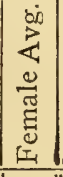 } & \multirow[b]{2}{*}{$\begin{array}{l}\frac{1}{5} \\
\frac{00}{0} \\
3 \\
3\end{array}$} & \multirow{2}{*}{ 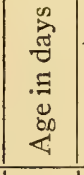 } & \multicolumn{2}{|c|}{ Male Av. } & \multicolumn{2}{|c|}{ Fem. Av. } & \multirow{2}{*}{$\begin{array}{l}0 \\
0 \\
0 \\
. \\
. \Xi \\
0 \\
\infty \\
c\end{array}$} & \multirow[b]{2}{*}{ 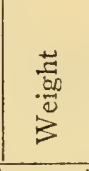 } & \multicolumn{2}{|c|}{ Male Av. } & \multicolumn{2}{|c|}{ Fem. Av. } \\
\hline & & & & & & & & & $\begin{array}{l}\frac{\overrightarrow{6}}{600} \\
\frac{0}{3} \\
3\end{array}$ & 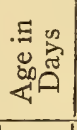 & $\mid \begin{array}{l}\frac{7}{5} \\
\frac{0}{00} \\
3\end{array}$ & 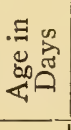 & & & $\frac{\overrightarrow{3}}{300}$ & 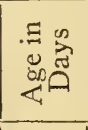 & $\begin{array}{l}\frac{1}{6} \\
\frac{600}{0} \\
3\end{array}$ & 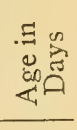 \\
\hline \multirow{4}{*}{$\begin{array}{r}\text { Pmnivorous } \\
\text { Exercised } \\
\text { Rats..... }\end{array}$} & I & 1 & 2 & $30 \mid$ & . & & 252 & 44 & & & & & $2 \mathrm{I} 4$ & 746 & & & & \\
\hline & 2 & 1 & 43 & 30 & $4 \mathrm{I}$ & $\because$ & 272 & 7 & 262 & 534 & & & & 925 & 212 & 819 & & \\
\hline & 3. & $\mathrm{~F}$ & 37 & 29 & . & 37 & 176 & O9 & & & 176 & 509 & 128 & IOI 4 & . & & I 28 & 10 \\
\hline & 4 & I & 39 & 29 & . & - & 261 & 560 & & 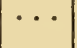 & & & $2 \mathrm{I} 5$ & 785 & . & & . & \\
\hline \multirow{4}{*}{$\begin{array}{c}\text { Vegetarian } \\
\text { Exercised } \\
\text { Rats...... }\end{array}$} & 5 & $\mathrm{M}$ & 36 & 30 & 36 & $\cdots$ & I45 & 544 & I 45 & 544 & 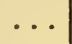 & & 96 & 685 & 96 & 685 & 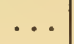 & \\
\hline & 6 & $\mathrm{~F}$ & 42 & 30 & $\cdots$ & . & IIO & 25 & .. & $\ldots$ & . & & 97 & $38 \mathrm{I}$ & $\cdots$ & $\cdots$ & . & \\
\hline & 7 & $\mathrm{~F}$ & 40 & 29 & .. & 39 & I29 & $25 \mathrm{I}$ & & $\cdots$ & I 24 & $33^{8}$ & 100 & 463 & 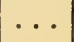 & 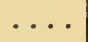 & 9. & \\
\hline & 8 & $F$ & 36 & 29 & . & . & I32 & 509 & & 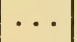 & - & $\cdots$ & 84 & 682 & $\cdots$ & & . & \\
\hline \multirow{4}{*}{$\begin{array}{c}\text { Omnivorous } \\
\text { Control } \\
\text { Rats..... }\end{array}$} & 9 & $\mathrm{M}$ & 3 & $3 c^{\circ}$ & . & & & 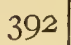 & & & & & 247 & I074 & & & & \\
\hline & IO & $\mathrm{M}$ & 45 & 30 & $4 \mathrm{I}$ & $\because$ & 331 & 392 & 320 & 391 & & & 165 & $13^{6} \mathrm{I}$ & $24 \mathrm{I}$ & 1222 & & \\
\hline & II I & $\mathrm{F}$ & 39 & 29 & . & 39 & 200 & 337 & & & 200 & 337 & I35 & $360 \dagger$ & $\cdots$ & & I35 & 3 \\
\hline & 12 & $\mathrm{M}$ & 45 & 29 & $\cdots$ & . & 319 & 390 & & & & & I 72 & 1232 & $\ldots$ & & $\cdots$ & \\
\hline \multirow{4}{*}{$\begin{array}{c}\text { Vegetarian } \\
\text { Control } \\
\text { Rats..... }\end{array}$} & I3 & $F$ & 37 & 30 & . & 37 & 164 & 3 & & & I64 & 392 & I 50 & 778 & $\cdots$ & & $\mathrm{I}_{50}$ & 77 \\
\hline & 14 & $\mathrm{M}$ & 47 & 30 & $\because 1$ & & I85 & 283 & & & & & I63 & 373 & & & . & \\
\hline & I 5 & $\mathrm{M}$ & 42 & 29 & 44 & $\cdots$ & 209 & 390 & I95 & 342 & & & I I7 & 578 & I 29 & 484 & 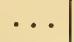 & \\
\hline & I6 & $\mathrm{M}$ & 42 & 29 & 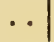 & $\cdots$ & I9I & 353. & & & & & I07 & 500 & $\cdots$ & & & \\
\hline
\end{tabular}

TABLE X.-Showing the difference between the omnivorous and vegetarian rats in regard to the age and weight at the beginning of the experiment, the prime of life, and the death of each individual.

*This weight was taken I4 days before death and is therefore heavier than it should be.

$\dagger$ This rat was killed because of sickness. 


\section{LENGTH OF LIFE.}

The various tables and curves so far given show in a general way the comparative length of life of these two groups of animals. A more detailed comparison will be necessary.

In Table $\mathrm{X}$ the age of the death of each rat is given, also the average age of each sex comprising the various groups. When the same sex is compared it is noticed that the omnivorous feeders surpass the vegetarians in longevity by a good margin. The only exception was No. Ir, which should not be used in these comparisons as it was killed on account of sickness. When the averages are compared the contrast

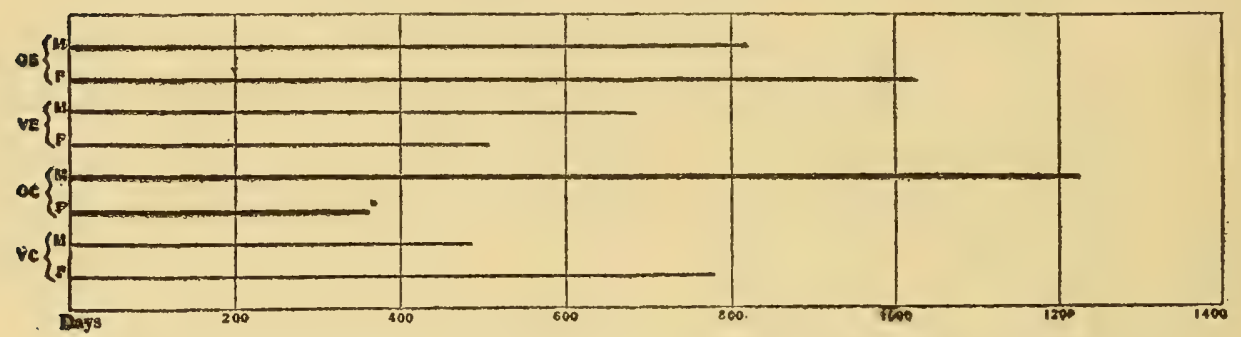

Fig. 18. Diagram representing the average age of each sex of the four groups. $O E$ omnivorous exercised; $V E$, vegetarian exercised; $O C$, omnivorous controls; $V C$, vegetarian controls. $M$ and $F$ refer to male and female.

is still more pronounced. These averages are put in diagramatic form in Figure I8. The horizontal lines represent the average age at death of each sex in the different divisions.

$\mathrm{OE}, \mathrm{VE}, \mathrm{OC}$ and $\mathrm{VC}$ refer to omnivorous exercised, vegetarian exercised, omnivorous control, and the vegetarian rats, respectively. The relatively short duration of life of the vegetarians is very conspicuous.

If the average lifetime of all the omnivorous males is compared with the average of all the vegetarian males, we find a ratio of 1020 days to 534 days; or I.9I : I. When the females are similarly com-

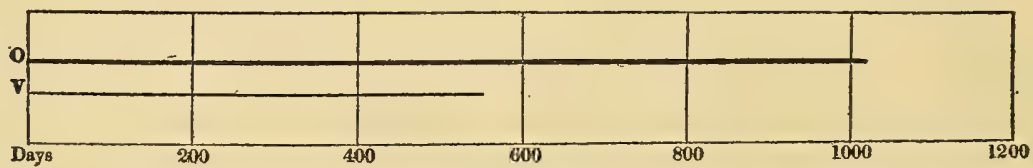

Fig. 19. Diagram showing the average lifetime of all the omnivorous rats $(O)$ and all the vegetarians $(V)$.

*This rat was killed at this age because of illness. 
pared the omnivorous averaged Ior 4 days, and the vegetarian 574 days, or a ratio of $1.77: I$. If the average of all the omnivorous, including both sexes, is compared with the average of all vegetarian rats we have the relation of I020 days to 555 days, or a ratio of $1.84: I$.

Figure I9 shows in graphic form the total average lifetime of the omnivorous rats $(\mathrm{O})$ and of the vegetarians (V). The first group lived almost twice as long as the last. This is a decided difference. When we recall that all these animals were of the same age and as nearly as possible the same parentage, were subjected to similar environment, and fed exactly the same food, with the exception that the omnivorous group received animal food in addition about three times a week, we must conclude that this great difference is due to the presence of this animal food and to nothing else.

\section{GENERAL APPLICATIONS AND COMPARISONS.}

Any attempt to make a practical application of these results to man, will no doubt be severely criticised by some on the ground that what is true of the albino rat would not hold true in man, owing to the wide difference in zoological position. Such a criticism would be based on the prevalent idea that man is a supreme being, occupying a place above animals, and with which he is not to be compared.

The rat is by nature an omnivorous animal. All evidence points to the fact that man is by nature an omnivorous animal. The character of the teeth and the digestive tract throughout are best adapted to a mixed diet. His nearest related kin in the animal kingdom-the anthropoid apes-are all omnivorous feeders. In his savage state he partakes of the food most accessible, which includes animal food whenever it is possible to secure it. There is probably no animal as capable of adapting itself to so great changes in environment and in diet as man. But though he is able to adapt himself to a restricted diet, is such a diet capable of developing and maintaining his maximum mental and physical energy for a long period of life? It is not a question of what food will keep the animal alive, but what diet will make it the most efficient machine. It is not so much a problem of determining what foods are necessary to maintain nitrogenous equilibrium in man, as it is of ascertaining what diet is necessary not only to prolong mental and physical efficiency during a long period of life, but to produce initiative in these respects.

The rats fed on the mixed diet had by far the greater initiative and 
ability for muscular work. The mental ability was not tested, but one would judge from their appearance and alertness that they would far surpass the vegetarians in this respect.

A perusal of the literature of this subject convinces one of the fact that the results of the experiments on the rat can be applied to other animals, including man.

Jaffa, ${ }^{6}$ in his investigations on a family of fruitarians, says that the youngest child which had lived from infancy on nuts and fruit "was certainly undeveloped. Her bones were very small, although she had no tendency toward rhachitis. She looked fully two years younger than she was." The diet was not satisfying and the craving for other foods was occasionally satisfied by eating them. All the family were below size.

Chittenden fed dogs on vegetable foods and animal fat with disastrous result. In referring to this he says: "This is by no means an exceptional case, but we can cite many examples of like results where the animals when restricted to a purely vegetable diet, such as bread, pea-soup, bean-soup, etc., re-enforced by an animal fat, quickly passed from a condition of health into a state of utter wretchedness, with serious gastro-intestinal disturbance."

Caspari, ${ }^{8}$ in studying the effect of a vegetarian diet on man, found that he could not maintain his body weight, but lost $\mathrm{I} 3 \mathrm{~K}$ during the experiment. Milk and butter had to be added. In another person he found that he could maintain his weight on a vegetable diet. $\mathrm{He}$ was, however, very thin, and the amount of protein in the faeces was large. These experiments lasted for only a short time.

Langworthy, ${ }^{\circ}$ in discussing food and diet in the United States, says: "In general, the food habits of the human race today are an expression of the thousands of years of experience in which man has sought to bring himself into harmony with his environment, and food habits have been determined, as regards materials selected, by available supplies, man being by nature omnivorous." Man likes variety. People of the United States are well nourished compared with other races. He further says: "The acknowledged energy and achievements of the American people, together with their general good health and physical well-being, certainly indicate that we have in the main used our food resources advantageously."

In regard to the digestibility of animal and vegetable foods, we find investigators pretty closely agreeing in their results. Albu, ${ }^{10}$ in metabolism experiments on a vegetarian, found that only $67 \%$ of the protein and $65 \%$ of the fat of this food was digested. Snyder, ${ }^{11}$ in 
discussing the comparative digestibility of animal and vegetable protein, says that $95 \%$ of the former and $85 \%$ of the latter are digested. Benedict, ${ }^{12}$ in comparing the digestibility of animal proteins and fats, found that $97 \%$ of animal protein is digested and $84 \%$ of vegetable protein. In a mixed diet he found that $92 \%$ of the protein was digested. In regard to fats he found that $95 \%$ of animal fat was absorbed and a less amount of vegetable fat. Many other investigators have found that vegetable protein is not used by the body to the same extent as animal protein. ${ }^{13} 14$

In regard to the effect of diet upon activity, Thompson, ${ }^{15}$ in his studies on dietetics, says: "Meat in general has a more stimulating effect upon the system and is more strengthening than vegetable food, and it gives rise to the sensations of energy and activity." A person ${ }^{16}$ who changed from a mixed diet to a vegetable one, in describing the effect says: "I, too, felt chilled and sleepy by day and night, so tired that I could hardly walk." This describes the general appearance of the vegetarian rats very closely. $\mathrm{Nitti}^{17}$ in accounting for the greater efficiency of the Italians in the United States than in Italy, attributes it to the fact that their diet here is richer in protein, containing a greater proportion of meat.

In regard to the amount of protein required, most of the results again are in close accord.

Caspari ${ }^{18}$ concludes that the minimum amount of protein required varies with different individuals, and may also vary in the same individual within wide limits. This is shown in the dietary study ${ }^{19}$ of Sandow, the "Strong Man," who consumed 244 grams of protein each day. This is far above the average.

Chittenden (7) has demonstrated that man can maintain his nitrogenous equilibrium on a diet containing far less protein than the average diet. He has not, however, carried this far enough to determine what effect such a diet would have on the life of the individual or the race.

Shutt ${ }^{20}$ found that in hogs fed on a low protein diet-corn onlythe meat was inferior and soft. When additional protein was added in the form of milk, the meat was greatly improved. He also states that hogs fed on too high a protein diet had inferior meat. These results were confirmed by Skinner. ${ }^{21} \mathrm{He}$ adds that hogs fed on corn meal have "poor appetite, light bone, deficient development in valuable portions of the carcasses, and a general state of unthrift, as shown by the hair, skin, and hungry look of the animal." When one-sixth of the amount of normal ration rich in protein was added the hogs had normal growth and were in healthy condition. 
Haecker ${ }^{22}$ experimented on two groups of cows, the first group having a normal amout of protein and the second group a low amount. No difference was noticed at the end of the second year, except that the second group weighed less. Soon after this time the second group began to decline. They grew thin, hair became harsh, and their condition became generally poor, showing under-nutrition. The amount of protein had to be increased in order to preserve their lives. Here we see that this group did well for two years before any serious effects were manifested. A similar result was found in the rats experimented upon. The rats first showed a difference in weight. Later at the age of three or four months changes in the activity and general condition began to appear. One is not warranted, therefore, in drawing sweeping conclusions of the effects of certain diets on any animal from a few weeks' or months' experimentation.

$\mathrm{McCay}^{23}$ studied the effect of the native diet, low in nitrogen and rich in non-nitrogenous foods, on the physical condition, the health and the efficiency of the Bengalis, compared to European diet and Europeans in the University of Bengal. From the data of body weight, height and chest measurement of 2,500 Bengali students he concludes that the Bengalis "do not reach the same standard of general physique as is attained by races of European origin; and yet from the evidence we can find no cause inherent in the Bengali as a race for this deficiency; on the contrary, we consider that there may be a very close relationship between the lower physical development of this people and the meager protein contents of the diet on which they subsist." In comparing growth of the Bengali and European students he says: "The two classes enter college about the same age, live in the same climate and under very similar conditions . . . but the results at the end of their college career are very different. The European boys develop into strong, healthy men quite up to the average of European standards, while the Bengali students almost remain stationary as regards development." He finds that the Europeans are much more capable of endurance.

Watson and Hunter ${ }^{5}$ have shown that when young rats are fed on a diet of rice the growth is arrested and death results in two or three months. When fed on a porridge diet made by boiling together oatmeal, milk, water and salt the growth was arrested and death resulted within four months. They were evidently not able to assimilate this food even though it was reasonably rich in protein. When fed a strictly flesh diet the results were disastrous in most cases when the rats were very young. When rats two or three months old were put on an 
exclusively ox-flesh diet the result was favorable, growth being promoted, the anmials reaching a larger size than the normal control rats.

In regard to races of men it is interesting to note that those whose stature is large partake freely of meat, while those of small physique live largely on a vegetable diet.

Oshima ${ }^{25}$ says in regard to the Japanese: "Among the ordinary families in the rural district the use of meat is (of necessity) restricted chiefly to festive occasions; and among the poorer peasantry even rice is used at such times." He further says that the poorer classes of cities and country, comprising about $75 \%$ of the total population, are vegetarians from force of financial circumstances rather than from principle. They eat animal food whenever they can get it. This usually consists of fish two or three times a month, and meat two or three times a year.

Boas $^{26}$ found that the North American Indians living on the mountains are smaller than those living on the plains. He attributes this to greater abundance of rich food on the plains.

Sill, ${ }^{27}$ in his study of malnutrition of the school children in New York City, found that out of 2 Io cases, $83 \%$ practically depended on vegetable food, consisting largely of bread, tea and coffee.

Albertoni and Rossi ${ }^{28}$ found that when meat was added to the diet of the peasants of the Abruzzi region, who had been almost exclusively vegetarians for generations, there was an increase in power of assimilation, in body weight, and in physical power.

Houssay ${ }^{29}$ in his experiments on chickens fed exclusively on animal and vegetable rations, found that the chickens fed on animal food grew much faster than those fed on vegetable rations. This corresponds closely to my experiments on the rats.

These results correspond closely with those of Bolté. ${ }^{30} \mathrm{He}$ fed chickens on a number of rations, and concludes: "In the absence of skim milk to mix with the grain, some other animal concentrate should be supplied. A ration containing 10\% of animal meal gave a much greater gain than rations containing either no animal meal or $20 \%$ animal meal. The cost of feed per pound of gain was lessened onethird under the same condition.

In regard to therapeutics, diet has a great value.

Rubner, ${ }^{31}$ in his studies on the diet of the poor who have lived largely or wholly on vegetables, concludes that this diet is the cause of lack of physical condition and ability for work; that it causes an increase in morbidity and mortality by lowering the ability to resist epidemic diseases.

In the treatment of tuberculosis it has been found ${ }^{82}$ that food with a rich protein content is of great value. 
$\mathrm{McCay}^{23}$ finds that kidney disease is much more prevalent in native inhabitants of Bengal than in Europeans who live there. $\mathrm{He}$ attributes this to their diet, which is low in protein.

Thompson, ${ }^{15}$ in regard to power of vegetarians to resist disease, says: "In regard to an exclusive or almost exclusive vegetable diet for man, the universal experierice has been that while it may keep him in apparent health for some time, it eventually results in a loss of strength and general resisting power against disease, which becomes evident after some months, if not before .... Animal food in some form must be regarded as absolutely essential for all vigorous races."

It is claimed that vegetarians convalesce more slowly after a period of illness. ${ }^{33}$ That animal food makes blood richer in red corpuscles and gives firmness to muscle without excess of fat. ${ }^{34}$

In $\mathrm{r} 883$, when the diet consisted largely of rice, $33 \%$ of the Japanese marines had beri beri. In 1884 meat and bread were added to the rations, and now they hardly have three cases a year. ${ }^{7}$

When the effects of a restricted diet and of various diets upon the resistance of animals to certain poisons are considered, Hunt ${ }^{24}$ has found that " diet has a marked effect upon the resistance of animals to certain poisons; the resistance of some animals may be increased forty-fold by changes in diet. Certain diets, notably dextrose, oatmeal, liver and kidneys, greatly increase the resistance of mice to acetonitril; their effect is similar in this respect to the adminsitration of thyroid. The experiments show that foods such as enter largely into the daily diet of man have most pronounced effects upon the resistance of animals to several poisons. They produce changes in metabolism which are not readily detectable by methods ordinarily used in metabolism studies. The ease and rapidity with which certain changes in function are caused by diet are in striking contrast with the essentially negative results obtained by the chemical analyses of animals fed upon different diets."

Hutchison ${ }^{33}$ claims that intellectual capacity and bodily energy are dependent on a mixed diet, and that "it is not without reason that the more energetic races of the world have been meat eaters."

A study of the dietaries of the various races of the world confirms this. Wherever we find advancement in civilization, great achievements in the arts and sciences, maximum mental and physical ability, thrift and success, we find that animal food has formed a prominent portion of the diet.

The numerous observations and experiments on man and other animals in regard to the effects of an exclusive vegetable diet, as com- 
pared to a mixed diet, upon the general condition of the animal, all agree. They show that the vegetable diet produces far inferior results in almost every respect. Man does more work on a mixed diet than he did on a vegetable diet or almost exclusive vegetable diet. Man attains a greater stature on a mixed diet rich in protein than on vegetable food. Man has made more advancement and achieved more intellectually and physically on a mixed diet than on a vegetable one. He is able to maintain his body weight and physical well-being best on a mixed diet.

The results of the experiments on the albino rats correspond so closely with those on man and other animals that one is almost justified in concluding that if man were subjected to the same conditions of food for his lifetime the results in regard to voluntary activity, growth and longevity would be the same.

\section{CONCLUSIONS.}

When two groups of young rats of the same age and as nearly as possible the same parentage are subjected to the same environment and conditions, with the exception that one group has a vegetable diet and the other has the same vegetable diet plus animal food, the following results were obtained:

I. The omnivorous feeders are much more active and voluntarily do much more work during their lifetime than the vegetarians. The average ratio of efficiency is $7.5: \mathrm{I}$.

2. The females surpass the males of the same group in activity. This difference is greater in the omnivorous than in the vegetarian rats.

3. This difference did not become very noticeable until the experiment had proceeded two or three months; or until about one-fifth of the total life of the vegetarians had been lived. One cannot conclude, therefore, that a diet used for a few weeks is not injurious if no bad results occur during that time.

4. The total work accomplished by the vegetarians during their life was performed by the omnivorous rats when but $20.9 \%$ of their lives had been lived.

5. The vegetarian rats age much earlier in life, it requiring almost half their lifetime to perform the last one-eighth of their life's work, as compared to three-tenths for the omnivorous rats.

6. The growth of the vegetarians was greatly retarded. The ratio of maximum weights was as $1.62: \mathrm{I}$ in favor of the omnivorous feeders. 
7. The effect on general conditions of the body was most overwhelmingly in favor of the omnivorous. The vegetarians were frail, weak, and showed extreme lassitude and indifference. The omnivorous were the reverse in all these respects.

8. The average life of the omnivorous was Ioro days, that of the vegetarian 555 days. This was a ratio of $1.84: \mathrm{I}$.

9. The control rats in stationary cages lived longer than the exercised rats of the same group.

Io. All of the omnivorous rats surpassed the greatest age attained by the oldest vegetarian rats.

II. From numerous observations and experiments of other investigators on man we would infer that similar results would obtain if he were subjected to similar conditions throughout his lifetime. 


\section{REFERENCES.}

I. Slonaker, J. R. : The Normal Activity of the White Rat at Different Ages. Jour. Comp. Neurl. and Psychol., r907, Vol, 17, pp. 342-359.

2. Slonaker, J. R.: The Normal Activity of the White Rat from Birth to Natural Death, Its Rate of Growth and the Duration of Life. Journ. of Animal Behavior, Jan.-Feb., I912, Vol. 2, No. I, pp. 20-42.

3. Minot, C. S.: On the Weight of Guinea-Pigs. Journ. of Physiol., r89r, Vol. I2, pp. 98-I53.

4. Slonaker, J. R.: Description of an Apparatus for Recording the Activity of Small Mammals. The Anat. Record, June I908, Vol. 2, pp. II6-I22.

5. Watson, C. and Hunter, A.: Observations on Diet. The Influence of Diet on Growth and Nutrition. Journ. Physiol., Vol. 34, 1906, pp. III-I32.

6. Jaffa, M. E.: Nutrition Investigations among Fruitarians and Chinese in California, 1899-1901. U. S. Dept. Agr., Office of Exp. Sta., Bul. I07, I90I, pp. I-43. 7. Chittenden, R. H.: The Nutrition of Man. Frederick A. Stokes Co., New York, 1907, p. 321 .

8. Caspari, W.: Physiologische Studien über Vegetarismus. Arch. f. Physiologie (Pflüger's), Bd. I09, 1905, pp. 473-495.

9. Langworthy, C. F.: Food and Diet in the United States. U. S. Dept. Agr. Year-book, 1907, pp. 36I-378.

Io. Albu: Metabolism on a Vegetarian Diet. Ztschr. Klin. Med. (Berlin), Bd. 43 (I90I).

II. Snyder, H.: Human Foods. The MacMillan Co., New York, I908.

12. Benedict, F. G.: The Nutrition Requirements of the Body. Amer. Journ. Physiol., Vol. I6, I906.

13. Rockwood, E. W.: The Utilization of Vegetable Proteids by the Animal Organism. Amer. Journ. Physiol., Vol. II (I904), pp. 355-369.

I4. Bryant, A. P. and Milner, R. D.; Experiments on the Digestibility of Vegetables. Amer. Journ. Physiol., Vol. io (1903), pp. 8I-99.

I5. Thompson, W. G. : Practical Dietetics. With special reference to Diet and

Disease. D. Appleton \& Co., 2 d edition, I903, pp. I-828.

16. Paget, Lady Walb: Vegetable Diet. Pop. Sc. Mo., XLIV, pp. 94-Io2.

17. Nutti, The Economical Journal, Vol. 6, 1896, p. 21.

18. Caspari, W.: A Diet with a Small Amount of Protein. Arch. Anat. u. Physiol., Physiol. Abt., I901, pp. 323-337.

19. Langworthy, C. F.: Dietary Study of Sandow, the "Strong Man." Connecticut Storrs Sta. Rept. 1896, pp. I58-162.

20. Shutt: Experiments on Swine. Bul. 38, Dept. Agr., Ottawa, Can.

2I. Skinner: Experiments on Swine. Indiana Agr. Exp. Sta., Bul. I08. Minn.

22. Heacker, T. L. : Experiments on the Feeding of Cows. Exp. Sta. Univ.

23. McCay, D.: Constituents of the Urine and Blood and the Bearing of the Metabolism of Bengalis on the Problems of Nutrition. Sci. Mem. Med. and Sanit. Depts., India, N. Ser., 1908, No. 34, p. 67.

24. Hunt, R.: The Effects of a Restricted Diet and of Various Diets upon the Resistance of Animals to Certain Poisons. Pub. Health and Mar. Hosp. Serv. U. S., Hyg. Lab. Bul. 69, p. 93. 
25. Oshima, K.: A Digest of Japanese Investigations on the Nutrition of Man. U. S. Dept. Agr., Office Exp. St., Bul. 159, 1905, pp. I-I24.

26. Boas: Mem. of the Internat. Congress of Anthropology, Chicago, I893. 27. Sill, E. M.: A Study of Malnutrition in the School Children. Journ. Amer. Med. Assoc., 52 (1909), No. 25, pp. I981-1985.

28. Albertoni, P. and Rossi, F.: The Effect of Adding Meat to a Vegetarian Diet. Arch. Expt. Path. u. Pharmkol., 1908, Supp. pp. 29-38.

29. Houssay, F.: Animal Food for Chickens. Arch. Zool. Expt. et Gén., 4. Ser., 6 (1907), pp. I37-332.

30. Bolté, J. W.: Feeding Experiments with Chickens, Cockerels and Turkeys. Rhode Island Sta. Bul. I26, pp. I25-I39.

3r. Rubner, M.: Diet of the Poor, and Its Social Conditions. Rev. Hyg. et Pol. Sanit., 29 (I907), No. 9-10, pp. 854-855.

32. Lannelongue, Achard and Gaillard: Infuence of Food on the Progress of Experimental Tuberculosis. Compt. Rend. Acad. Sci. (Paris), I45 (I907), No. 20, pp. $785,786$.

33. Hutchison, Robert: Food and the Principles of Dietetics. I900, pp. I-548. London, Edward Arnold, Pub.

34. Pavy, F. W.: Food and Dietetics. 2d ed. I875, London, p. 613, J. and A: Churchill, Pub. 




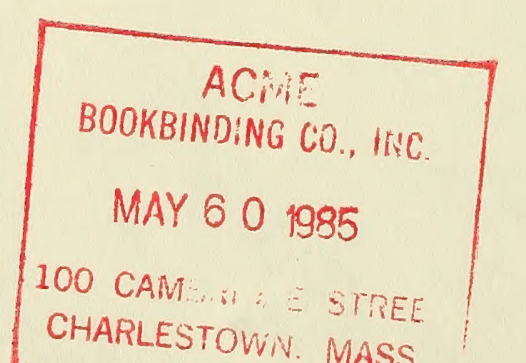


